Discussion Paper No. 15-002

Candidate Screening for the Recruitment of Critical Research and Development Workers - A Report and Preliminary Results with Evidence from Experimental Data from German High-Tech Firms

Katharina Frosch, Dietmar Harhoff, Karin Hoisl, Christian Steinle, and Thomas Zwick

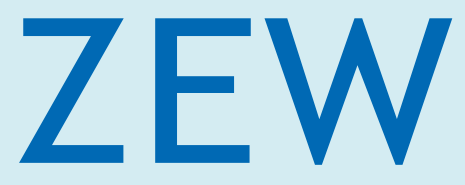

Zentrum für Europäische Wirtschaftsforschung $\mathrm{GmbH}$

Centre for European

Economic Research 
Discussion Paper No. 15-002

\title{
Candidate Screening for the Recruitment of Critical Research and Development Workers - A Report and Preliminary Results with Evidence from Experimental Data from German High-Tech Firms
}

\author{
Katharina Frosch, Dietmar Harhoff, Karin Hoisl, \\ Christian Steinle, and Thomas Zwick
}

Download this ZEW Discussion Paper from our ftp server:

http://ftp.zew.de/pub/zew-docs/dp/dp15002.pdf

Die Discussion Papers dienen einer möglichst schnellen Verbreitung von neueren Forschungsarbeiten des ZEW. Die Beiträge liegen in alleiniger Verantwortung der Autoren und stellen nicht notwendigerweise die Meinung des ZEW dar.

Discussion Papers are intended to make results of ZEW research promptly available to other economists in order to encourage discussion and suggestions for revisions. The authors are solely responsible for the contents which do not necessarily represent the opinion of the ZEW. 


\title{
Candidate screening for the recruitment of critical research and development workers - A report and preliminary results with evidence from experimental data from German high-tech firms
}

\author{
Katharina Frosch ${ }^{\mathrm{a}}$, Dietmar Harhoff ${ }^{\mathrm{bcd}}$, Karin Hoisl ${ }^{\mathrm{bc}}$, Christian Steinle ${ }^{\mathrm{b}}$, Thomas Zwick $^{\mathrm{ae}}$ \\ ${ }^{a}$ Chair of Human Resource Management and Organisation, Julius-Maximilians University \\ Wuerzburg \\ ${ }^{\mathrm{b}}$ Max-Planck-Institute for Innovation and Competition, Munich \\ ${ }^{c}$ Munich School of Management, Ludwig-MaximiliansUniversity (LMU), Munich \\ ${ }^{\mathrm{d}}$ Centre for Economic Policy Research (CEPR), London \\ ${ }^{e}$ Centre for European Economic Research (ZEW), Mannheim
}

\begin{abstract}
The report focuses on résumé-based screening strategies for the recruitment of highly qualified research and development (R\&D) workers (critical R\&D workers) in high-tech firms. We investigate which kinds of professional background, job-related experience, motivations, specific skills, and previous inventive activity make a candidate attractive for firms specializing in clean technology or mechanical elements. The report is based on a combination of survey and experimental data collected from 194 HR decision makers in German high-tech firms and from 89 technology experts in the clean technology and mechanical elements fields. A mixed logit model is used to analyse hiring preferences because this model allows us to deal with repeated choices. We find that HR decision makers prefer candidates with technology-specific patenting experience, an engineering background, analytical thinking skills, and a strong desire to develop path-breaking technologies. Furthermore, no one-size-fits-all candidate exists that is equally preferred in both technology fields. HR decision makers in mechanical element firms prefer specialists to generalists, whereas those in clean technology attach special importance to a candidate's orientation towards environmental concerns and sustainability.
\end{abstract}

\section{Acknowledgements}

The authors acknowledge financial support from Deutsche Forschungsgemeinschaft (DFG) (Reference No.: ZW 172/2-1, Term: 2012-2014). We also thank the OECD for providing us with a classification of clean technology patents. For able research assistance, we thank Sabrina Klassen and Alisa Wettengel. 


\section{$1 \quad$ Introduction}

The evaluation of résumés, also known as candidate screening, is conducted prior to job interviews in almost every recruiting process. Résumés are a convenient and cost effective means to assess education, work experience, and specific skills as well as extracurricular activities (Dipboye et al., 1984; Knouse, 1994; Cole et al., 2003, 2005, 2007, 2009).

In this report, we investigate the hiring preferences of decision makers in human resource (HR) management (HR decision makers) during pre-interview screening processes for research and development (R\&D) workers in high-tech firms in Germany. We use the term "HR decision makers" because small and medium sized firms do not necessarily have a separate HR department dealing with personnel selection. In these firms, the managing director or other members of the management board are in charge of HR.

The present report provides information about which kinds of professional background, jobrelated experience, career motivations, specific skills, and previous inventive activity HR decision makers in high-tech firms value most when selecting new R\&D workers. Our focus is on highly qualified $R \& D$ employees who play an important role in the development of path-breaking new technologies. We describe the potential hires as R\&D experts who have a key role in the invention process, but whose primary focus is technology development and not management; key inventors rather than project leaders. Building on the seminal work of Roberts and Fusfeld (1981), we call these R\&D workers "critical R\&D workers".

HR decision makers do not necessarily dispense with the in-depth technological background necessary for these hiring decisions. Consequently, it is common practice to involve technology specialists in the screening and selection procedures. Therefore, we also investigate peer ratings of $\mathrm{R} \& \mathrm{D}$ workers and compare them to the ratings of $\mathrm{HR}$ decision makers.

We propose that required qualifications vary between technology fields because, for example in emerging technology fields, such as clean technology (CT), skills like divergent thinking or a positive risk attitude may be more relevant than in more established traditional technology fields, such as mechanical elements (ME). Similarly, technology development in CT usually demands expertise from different fields. For instance, solar energy requires chemistry and electrical engineering. In contrast, $\mathrm{ME}$ focuses on the development of basic machine elements, such as clutches, brakes, bearings, springs, valves, or taps. Hence, we expect generalist knowledge to be particularly valued in CT, and specialized engineering knowledge to be valued more in ME.

Our empirical analysis is based on a web-administered conjoint experiment that realistically mimics the résumé evaluation stage in employee recruiting. We surveyed $194 \mathrm{HR}$ decision makers in German high-tech firms active in CT and/or ME as well as 89 technology experts in these technology fields and asked them to evaluate résumés of fictitious candidates for a job vacancy in their R\&D department.

In brief, this report has the following goals:

- providing background information about the survey and the choice-based experiment, including details of sampling issues, the design of the experiment and additional survey modules, data collection, and data processing,

- describing who takes HR decisions for R\&D vacancies in high-tech firms in Germany (experience, HR skills, analytical skills, values, and orientations),

- assessing the hiring preferences of HR decision makers in CT and ME based on an econometric model, and 
- providing an overview of other indicators available from the additional survey modules.

Please note that this report intends to inform the reader about the basic results of our project. It focuses on technical and data aspects and will be used as the basis for further publications and discussion papers.

The remainder of the report is structured as follows. Section 2 describes the research design and the research methods used. Section 3 provides descriptive statistics. In Section 4, the empirical model is presented and Section 5 concludes.

\section{Research design}

We want to identify the human capital components HR decision makers value most when taking hiring decisions for critical positions in $\mathrm{R} \& \mathrm{D}$ projects related to either ME or CT. Therefore, we conduct choice-based conjoint experiments (Green and Srinivasan, 1990). Survey participants repeatedly choose the best among multiple fictitious candidate profiles. The respondents' preference for each candidate characteristic is then determined indirectly by estimating its impact on the probability that the presented candidate is chosen, instead of letting respondents directly assess the importance of each human capital component. These discrete choice experiments realistically mirror decision making in hiring and selection in the real world (Fischer and Henkel, 2013, p. 329).

In this section, we first describe the data source and sample of the conjoint experiment (2.1), we then illustrate how we constructed the fictitious candidate profiles (2.2) and set up the experiment (2.3). Subsections 2.4 and 2.5 provide information on additional survey modules and the fielding of the survey ${ }^{1}$.

\subsection{Data source and sample}

The data for this report were collected through a self-administered survey of German HR decision makers and technology experts employed by firms active in CT or ME.

Firms involved in the development of new technologies in these fields were identified from patents filed with the European Patent Office (EPO). We extracted all patent applications between 2005 and 2008 from the EPO Worldwide Patent Statistical (PATSTAT) database as of April 2012. We restricted the sample to applicant firms located in Germany. To identify firms with patents in ME, the ISI-OST-INPI classification was used (Schmoch, 2008). To identify CT patents we used information from PATSTAT. The database contains an identifier for CT patents (Veefkind, 2012; Espacenet, 2012). Additionally, we received a list of CT patents from the OECD based on the taxonomy developed by the Environment Directorate of the OECD (ENV-TECH) ${ }^{2}$.

Patents classified as CT protect technologies or applications for mitigation or adaption against climate change. We focus on three subfields of CT: clean energy, clean transportation, and clean building.

- Clean energy. Technologies for reducing greenhouse gas emissions in energy generation, transmission, or distribution (e.g., related to renewable energy sources such as wind or solar power, combustion technologies with mitigation potential, or technologies for the production of fuel of non-fossil origin).

\footnotetext{
${ }^{1}$ Note that the estimation method for determining respondents' preferences is presented in Section 4.1.

${ }^{2} \mathrm{See}$ http://www.oecd.org/env/consumption-innovation/ENVtech\%20search\%20strategies\%20for\%20OECDstat\%20\%282013\%29.pdf, accessed on July 24, 2014.
} 
- Clean transportation. Climate change mitigation technologies for transportation (e.g., electric cars, transportation technologies for goods and passengers via road, railways, and waterways with the potential to reduce greenhouse gas emissions, and enabling technologies).

- Clean building. Climate change mitigation technologies that are focused on buildings, including housing and appliances or end-user applications (e.g., energyefficient heating or lightning technologies, thermal insulation of buildings, efficient home appliances, integration of renewable energy sources in buildings, and reduction of energy use based on ICT or power management tools)

A detailed description of the classification procedure and the search routines used is provided in Frosch et al. (2014a). For this report, we exclude patents filed by individual inventors, nonGerman firms, and organizations other than private firms (e.g., universities, private research organizations, or hospitals).

Overall, the search returned 2287 firms, of which 1357 firms had at least one patent in ME, 764 firms had at least one patent in CT, and 166 firms had patents in both fields. Applicants active in both fields were assigned to the technology in which they had filed more patents. Firms with an equal number of patents in $\mathrm{CT}$ and $\mathrm{ME}$ were assigned to $\mathrm{CT}^{3}$. Our final sample contained 1428 firms active in ME and 859 firms active in CT.

Because CT is still an emerging technology field compared with ME, identifying firms based on patents might overlook firms with technologies in a very early development stage (not yet patented) or start-ups. Therefore, we supplemented our CT firm sample with non-patenting firms that do R\&D in clean energy, clean building, and clean transportation. In the first step, potential firms were identified based on business registers and exhibition catalogues. To obtain a homogeneous sample of CT firms, only business registers and exhibition catalogues were used that were related to our three technological subfields: clean energy, clean building, and clean transportation. The initial search resulted in 5729 firms (first step). A detailed web search resulted in addresses of 952 firms that are located in Germany, that actively conduct R\&D in CT, but did not have any patents (second step). These additional CT firms are approximately equally distributed across the three subfields (Table 1).

Table 1: Results of manual address research for non-patenting firms.

\begin{tabular}{lcccc}
\hline Number of firms & Total & $\begin{array}{c}\text { Clean } \\
\text { Energy }\end{array}$ & $\begin{array}{c}\text { Clean } \\
\text { Building }\end{array}$ & $\begin{array}{c}\text { Clean } \\
\text { Transportation }\end{array}$ \\
\hline $\begin{array}{l}\text { all (first step of research procedure) } \\
\begin{array}{l}\text { relevant and still in existence (second step } \\
\text { of research procedure) }\end{array}\end{array}$ & 5729 & 1897 & 1973 & 1859 \\
hit rate & $17.4 \%$ & $19.3 \%$ & $17.9 \%$ & $15.0 \%$ \\
\hline
\end{tabular}

To get access to technology experts, we took a random sample of $150 \mathrm{ME}$ and $300 \mathrm{CT}$ inventors who filed at least one patent in their technology field between 2005 and 2008. Details of the search procedure for inventors are described in Frosch et al. (2014a).

\footnotetext{
${ }^{3}$ This decision does not affect our results because none of the companies that filed the same number of patents in both technology fields participated in the survey.
} 
Table 2 summarizes the size of the samples containing technology-developing firms with and without EP patents, and technology experts active in one of the two technology fields or both.

We mailed invitation letters to the HR decision makers of the technology firms inviting them to participate in the survey. The name and the postal addresses of patenting firms and the technology experts were obtained from the patent documents. The addresses of the nonpatenting firms were obtained via web searches. As we had the names and home addresses of the technology experts, we personalized their invitation letters. The letters to the HR decision makers were sent to the HR department in the firm.

The overall corrected ${ }^{4}$ response rate was $7.7 \%$ for firms and $24.9 \%$ for technology experts. The lower participation rate for firms may be because HR decision makers could not be addressed personally and we sent the invitation letter to the firm rather than to the private address of the respondents ${ }^{5}$ (Anseel et al., 2010, pp. 342 and 347). However, the response rate is within the expected range for surveys conducted with firms. Harhoff and Hoisl (2010) surveyed managers from German SMEs. Although they were able to personalize the invitation letter the response rate amounted did not exceed $13.5 \%$.

Table 2: Sample sizes and number of responses by technology field.

\begin{tabular}{lccccc}
\hline Firms & $\begin{array}{c}\text { Sample } \\
\text { size }\end{array}$ & $\begin{array}{c}\text { Responses } \\
(\mathbf{N})\end{array}$ & $\begin{array}{c}\text { Response } \\
\text { rate [\%] }\end{array}$ & $\begin{array}{c}\text { Corrected } \\
\text { response } \\
\text { rate [\%] }\end{array}$ & $\begin{array}{c}\text { Partici- } \\
\text { pation in } \\
\text { online } \\
\text { choice } \\
\text { experi- } \\
\text { ment }\end{array}$ \\
\hline Total & & & & & 2 \\
\hline HR decision makers in & & & & & $\mathbf{2 8 9}$ \\
technology firms, total & $\mathbf{3 6 8 9}$ & $\mathbf{3 4 0}$ & $\mathbf{9 . 2 \%}$ & $\mathbf{9 . 6 \%}$ & $\mathbf{1 9 4}$ \\
- ME, firms with EPO patents & 1428 & $\mathbf{2 4 3}$ & $\mathbf{7 . 5 \%}$ & $\mathbf{7 . 7 \%}$ & 89 \\
- CT, total & 1811 & 135 & $7.6 \%$ & $7.8 \%$ & 105 \\
- firms with EPO patents & 859 & 62 & $7.2 \%$ & $7.5 \%$ & 49 \\
- firms without EPO patents & 952 & 73 & $7.5 \%$ & $7.6 \%$ & 56 \\
technology experts, total & $\mathbf{4 5 0}$ & $\mathbf{9 7}$ & $\mathbf{2 1 . 6 \%}$ & $\mathbf{2 4 . 9 \%}$ & $\mathbf{8 9}$ \\
- ME & 150 & 40 & $26.7 \%$ & $29.9 \%$ & 36 \\
- CT & 300 & 57 & $19.0 \%$ & $22.4 \%$ & 53 \\
\hline
\end{tabular}

The majority of respondents completed the full online survey and showed high conscientiousness with respect to their answers, which provides us with high quality data with only a few missings. About $16 \%$ of respondents discontinued the online survey once they were introduced to the experiment. A possible explanation for this behaviour is that reading the instructions and taking part in the experiment would have demanded too much time and effort. Indeed, the 289 respondents who completed the experiment invested a median time of $1 \mathrm{~min}$ and 8 seconds for each of the 10 choice tasks presented (i.e. $11 \mathrm{~min}$ and $10 \mathrm{~s}$ altogether). Despite this considerable effort, most participants-if they did not drop out beforecompleted all 10 choice tasks (mean number of choice tasks completed, 9.0; 87\% of respondents completed all 10 choice tasks).This provided us with 8520 evaluated candidate profiles, of which 5850 of these valuations were from HR decision makers and 2670 from

\footnotetext{
${ }^{4}$ To calculate corrected response rates, firms and inventors who could not be reached because of wrong addresses, firms that had gone bankrupt or inventors who had passed away since filing the patent were excluded from the original sample (ME firms: 41, CT firms with EPO patents: 37, CT firms without EPO patents: 13, ME inventors: 16, CT inventors: 45).

${ }^{5}$ In smaller firms without a separate HR department, documents addressed to the HR department are usually delivered to the managing director or another member of the management board.
} 
technology experts. 55\% of the evaluated profiles were related to fictitious candidates in ME and $45 \%$ to fictitious candidates in CT.

\subsection{Design of the fictitious candidate profiles}

The evaluation of the candidate profiles has to be manageable from an information processing point of view, thus the number of characteristics that can be included in a choice experiment should be limited. Green and Srinivasam (1990, p. 8ff.) recommend a maximum of six attributes are used for a full-profile conjoint analysis. Although choice-based conjoint experiments, where respondents are presented several choice sets with only a few profiles each, may be conducted with more attributes (Orme 2010, p. 51ff.), we decided to restrict profiles to five candidate attributes with a maximum of three levels each. The overall setup of the conjoint experiment is also illustrated in Figure 1.

To meet the specific scope of our report, we focused the candidate profiles on knowledge, skills, and abilities that are possible indicators for pre-interview résumé-screening, namely characteristics that are commonly found in CVs and application documents.

We identified human capital resources that are potentially relevant for the development of path-breaking technological advances in ME and CT based on the existing theoretical and empirical literature. Many of the candidate characteristics we selected closely correspond to the componential theory of organizational creativity and innovation proposed by Amabile (1997), where expertise (attributes in this work: professional background and previous work experience), creative thinking (attribute levels in this work: creativity) and intrinsic task motivation (attribute in this work: main motivation for application) must be combined to allow creative achievements.

Figure 1: Design of the choice-based conjoint experiment with best-worst choice.

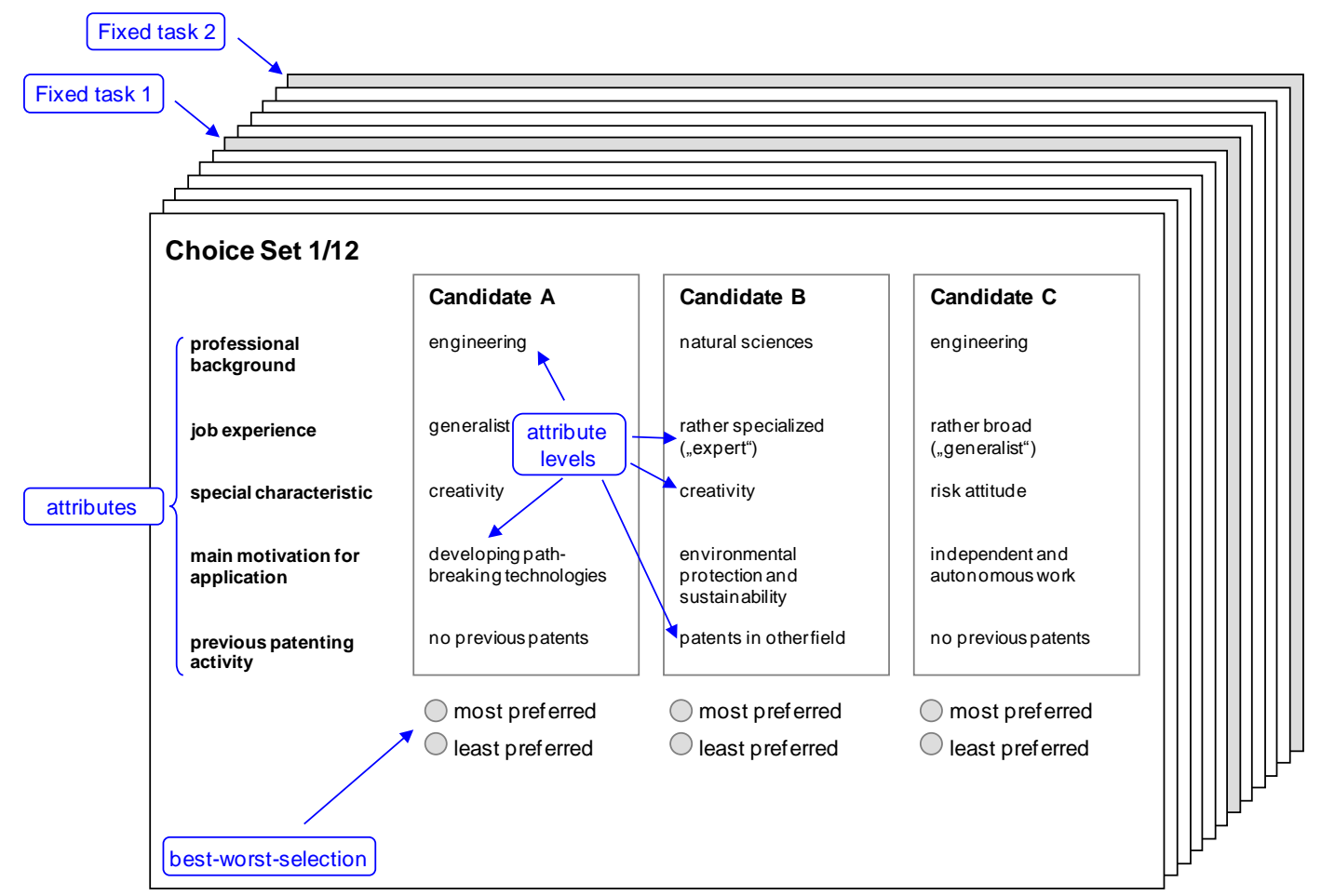

Next, we describe the different attributes used in our conjoint experiment. Gruber et al. (2013) showed that inventors with a scientific education are more likely to generate patents that span technological boundaries than inventors with an engineering degree. Boundary spanning 
should be more relevant in $\mathrm{CT}$ than in ME. Based on these results, we characterize the professional background of our fictitious candidates as "engineering" or "natural sciences".

In an earlier report based on the same dataset, we investigated drivers of inventive individual productivity, such as the breadth of work experience, risk attitude, divergent thinking abilities, and an analytical systematic style of problem solving and personality traits (Frosch et al., 2014b). We find that inventor characteristics closely related to creativity such as the ability for divergent thinking and openness to new experiences drive inventive productivity irrespective of the technology field. Furthermore, according to our report, the breadth of work experience and a positive risk attitude affect inventive productivity in CT. We, therefore, add breadth of previous work experience (specialist or generalist) and special skills such as risk attitude, creativity, and an analytical systematic problem-solving style ${ }^{6}$ to our candidate profiles.

We build on the theoretical work of Amabile (1997) that highlighted the role of intrinsic motivation for creative achievements. More specifically, we include information in the fictitious candidate profiles about what the main motivation of the candidates was in applying for the R\&D vacancy:

1. Developing path-breaking technologies as a motivation, which we would assume to be important for any kind of R\&D activity (i.e. the desire to see their ideas become a reality, enjoying working at the cutting edge, and innovating (Hebda et al., 2012)).

2. A taste for independent autonomous working, referring to earlier findings that individuals who perceive themselves as free in how they accomplish the tasks they are given are particularly creative (Amabile et al., 1996; Amabile, 1997; Abbey and Dickson, 1983).

3. Environmental protection and sustainability, which we expect to be a relevant motivation for an R\&D job in CT.

Finally, for the hiring organization the ability of inventors is hard to observe ex-ante. What can be observed is whether the inventors were listed on patent applications during the last couple of years prior to the application. Hence, the patenting activity of the inventors over the last years may indicate the inventors' ability (Spence, 1973; Hsu and Ziedonis, 2008). Therefore, we include information about the patenting activity in the past 5 years in the candidate profile. Table 3 summarizes the candidate attributes and the corresponding levels.

\footnotetext{
${ }^{6}$ An analytical, systematic problem-solving style has not proved to be a statistically significant driver of inventive productivity in the above mentioned study, but we include it as a commonly mentioned core competence for R\&D workers.
} 
Table 3: Attributes and levels in fictitious candidate profiles.

\begin{tabular}{ll}
\hline Attribute & Levels \\
\hline professional background & engineering \\
& natural sciences \\
job experience & rather specialized ("expert") \\
& rather broad ("generalist") \\
special characteristic & risk attitude \\
& analytical and systematic problem solving \\
& creativity \\
& developing path-breaking technologies \\
main motivation for application & independent and autonomous working \\
& environmental protection and sustainability \\
& no patents filed \\
previous patenting experience & at least one patent filed (any field) \\
& at least one patent filed in ME/CT
\end{tabular}

\subsection{Design of the choice experiment}

Respondents were asked to complete a choice-based conjoint experiment (CBC) (Louviere and Woodworth, 1983; Green and Srinivasan, 1990; Elrod et al., 1992; Chrzan and Orme, 2000). First, a basic scenario was presented. Survey participants were asked to imagine the following situation:

\footnotetext{
"Imagine you are a human resource manager in a technology firm. In three months, a new $R \& D$ project will start. Its scope is the development of path-breaking technological novelties in clean technology (e.g., renewable energies, energy-efficient buildings and clean mobility solutions). A considerable amount of financial resources is available for the implementation of the project.

Now there is a vacancy for an additional, highly qualified member of the R\&D project team. The new employee to be hired should be the driving force for the development of the technological novelties in clean technology.

Which candidates would you invite for an employment interview for the vacancy, and which rather not, if you solely had to decide based on the information provided in the following candidate profiles?"
}

The scenarios had been customized for the different types of respondents (the above scenario refers to HR decision makers in CT). Technology experts were asked to imagine being the manager of an R\&D project with focus on CT and, in this function, having to fill the abovedescribed vacancy by a suited candidate. Analogously, for HR decision makers and technology experts in ME the scenario referred to an $R \& D$ project in ME which was illustrated by naming appropriate example technologies (e.g., clutches, brakes, bearings, springs, valves, taps).

As our focus is on hiring preferences with respect to critical $R \& D$ workers who can drive the invention process of new technologies based on their knowledge, skills and abilities, in the scenario we emphasize that the selection decision should be relevant. More specifically, we mention that the new hire should be the driving force in the R\&D project, and that the project is equipped with a considerable financial budget.

We instruct the survey participants to assume that other candidate characteristics, such as school and study grade, the length of job experience, gender, temporal and geographical flexibility of the candidate, and salary expectations, are identical for all candidates presented. Concretely, we let them assume that the candidates have about 15 years of job experience, which further stresses that the scope of the experiment is selecting experienced "critical" R\&D workers. 
Each respondent was asked to go through 10 choice sets containing three hypothetical candidate profiles each, and to mark the best and the least suited candidates in every choice set. The 30 candidate profiles used to build the 10 choice sets for each respondent were chosen randomly from 500 profiles.

For the generation of choice tasks, we drew on a controlled random design for choice task generation with balanced overlap (Chrzan and Orme, 2000, p. 6f.). Huber and Zwerina (1996) note that the efficiency of choice designs is characterized by three (partly conflicting) aspects.

- Level balance: Levels of a candidate attribute occur with equal frequency.

- Orthogonality: Joint occurrence of any two levels of different attributes appear in profiles with frequencies equal to the product of their marginal frequencies (Addelman, 1962, as cited in Huber and Zwerina, 1996).

- Minimal overlap: Probability that an attribute level repeats itself in each choice set should be as small as possible.

Using balanced level overlap for choice set generation means that when generating the three profiles for one choice task, the co-occurrences of all pairs of attribute levels are tracked so that choice sets do not contain duplicate candidate profiles. However, some level of overlap between candidate characteristics is permitted. Minimal overlap between candidate attributes within one choice set is optimal with respect to the precision for the main effects (the preference for a certain candidate characteristic irrespective of its potential interplay with other candidate characteristics). However, some overlapping between candidate attributes has benefits for measuring interactions between attributes (Orme, 2009, p. 2f.). Overlapping, can also lead to more thoughtful responses, particularly if a respondent sees one candidate attribute as a must-have (Orme, 2009, p. 2f.). If only one candidate profile per choice set contains this must-have attribute, the respondent will always choose this profile without taking into account any other candidate characteristics. If two profiles contain the must-have attribute, the respondent is encouraged to ponder and express what additional aspects affect the selection decision.

To avoid attribute order effects, where the respondents always attribute the highest importance to the first attribute (Chrzan, 1994), we rotate the order in which the candidate characteristics appear in the choice set across respondents. Each respondent is randomly assigned a specific order of candidate characteristics, which are then used for the presentation of all candidate profiles.

Additionally to the 10 random choice sets, we presented two fixed choice sets. These choice sets were identically presented to all respondents (the attribute levels used for the $2 \times 3$ fixed tasks can be found in Table B.2, Appendix B).

\subsection{Survey structure and further survey modules}

We start the survey with questions on the respondents' demographic characteristics, such as gender and birth year (module A), their educational background, and their previous job experience, particularly with respect to HR management (HRM; module B) and their current employer and career position (module $\mathrm{C}$ ). These survey modules also serve as a warm-up for the experimental part of the survey because these questions are easy to answer for respondents.

In module D, respondents complete the choice-based conjoint experiment described above. 
Figure 2: Structure of the survey.

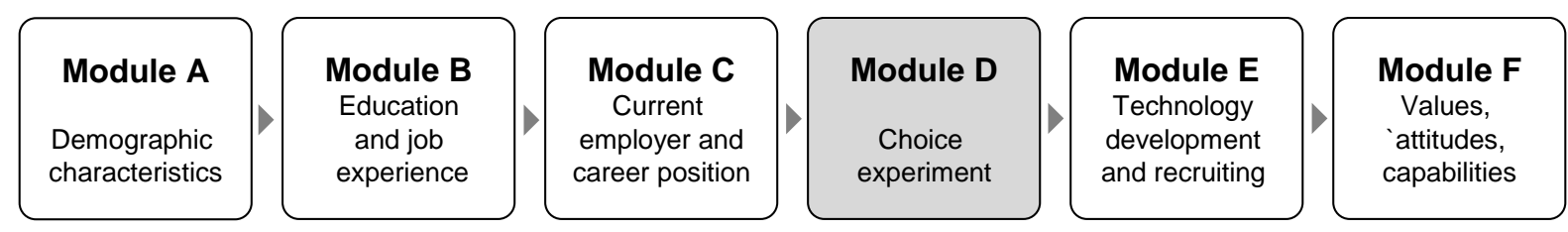

The subsequent modules again cover survey questions. They relate to technology development and recruitment at the respondents' current employers (module E), and provide insights into the respondents' risk attitude, their cognitive abilities, and their environmental and sustainability orientation (module F).

The structure of the survey both provides opportunities for further research (e.g., on heterogeneity in decision making between respondents with different characteristics and backgrounds), and makes the experiment a lively and interactive experience for respondents in order to avoid drop-outs.

For detailed descriptions of variables refer to Section 3 and Appendix A.

\subsection{Implementation and fielding of the survey}

The questionnaire and the choice experiment were implemented as a web-based survey using Sawtooth Software, which provides advanced features for designing choice-based conjoint experiments (Sawtooth, 2013).

The online survey instrument was developed and pre-tested with 22 HR experts (both researchers in HRM and business practitioners with HR responsibility) and three innovation experts between December 2013 and February 2014. The median time for completing the survey was $28 \mathrm{~min}$.

After completing the survey, we asked the pre-test respondents for feedback on how well the survey worked, how realistic the fictitious candidates were, whether the candidates covered the most important candidate characteristics, to what extent the survey was relevant to the respondents' professional practice, and finally whether the number of candidate profiles to be evaluated and the overall length of the survey was reasonable and feasible. The results of the pre-test are presented in more detail in Appendix C. Overall, the reactions were positive, so that the only substantial change was to shorten the experiment and the overall survey by about $20 \%$.

The final version of the online survey was implemented in February 2014. Invitation letters were sent out to 3239 firms and 450 technology experts in March 2014, containing a link to our online survey. A reminder letter was sent out in May 2014, resulting in a total of 243 responses from HR decision makers and technology experts (for details on response rates, see Section 3.1 and Table 2). The survey was closed in August 2014.

\section{Descriptive exploration of the data set}

The following descriptive statistics refer to the answers we collected from the HR decision makers and technology experts. These and further descriptive indicators are shown in Table A.1 and A.2 in Appendix A. For HR decision makers, indicators are also grouped by technology field (ME vs CT). These tables include a t-test or a Chi2-test to evaluate whether differences between technology fields are statistically significant. If not stated otherwise in 
the text, there are no significant differences between technology fields. Comparisons across technology fields are not provided for technology experts, because the focus of our report is comparing the hiring preferences of $\mathrm{HR}$ decision makers in $\mathrm{CT}$ and $\mathrm{ME}$, and technology experts are primarily used as an overall control group to indicate whether their views on critical R\&D workers are completely different from HR decision makers.

\subsection{Demographic characteristics (Module A)}

On average, HR decision makers are 43 years old. The mean age is computed based on the arithmetic mean of the boundaries of the age categories spanning 10 years as provided in the respective survey question, using 20-30 years for the youngest ${ }^{7}$ and 70-80 years for the oldest age group 8 . The gender ratio between male and female respondents for HR decision makers is about 40:60. Technology experts are significantly older (54 years) and predominantly male $(98 \%)$.

\subsection{Educational background and previous job experience in HRM (Module B)}

Of the HR decision makers, $70 \%$ graduated with a tertiary education degree, mostly in economics and business (53\%), social sciences (13\%), or law (5\%). Few have a background in engineering $(8 \%)$ or natural sciences $(4 \%)$. The remaining HR decision makers have a vocational degree (25\%), mostly from a commercial apprenticeship (94\%). About half of HR decision makers specialized in HRM during their studies or their vocational education.

Technology experts tend to have a higher level of education compared with the HR decision makers ( $87 \%$ have graduated with a tertiary degree), and the majority of experts have a background in engineering $(80 \%)$ or natural sciences $(18 \%)$.

Table 4 illustrates respondents' experience in leadership and personnel management as well as personnel selection. Almost all HR decision makers have been involved in personnel selection in the past 5 years, whereas this is only the case for $74 \%$ of technology experts.

Table 4 also reveals that, when asked to assess their level of experience in leadership and personnel management, HR decision makers in CT firms mainly have average practical experience, whereas most HR decision makers in ME think that their experience level corresponds to an expert or even to the highest (professional) level.

\footnotetext{
${ }^{7}$ In the survey: younger than 30 years.

${ }^{8}$ In the survey: older than 70 years.
} 
Table 4: Experience in leadership, personnel management and personnel selection.

\begin{tabular}{|c|c|c|c|c|c|c|c|c|}
\hline & \multicolumn{6}{|c|}{ HR decision makers } & \multicolumn{2}{|c|}{$\begin{array}{l}\text { Technology } \\
\text { experts }\end{array}$} \\
\hline & $\underset{\%}{\mathbf{A L L}}$ & $\mathbf{N}$ & $\begin{array}{c}\text { ME } \\
\%\end{array}$ & $\mathbf{N}$ & $\begin{array}{c}\text { CT } \\
\% \\
\end{array}$ & $\mathbf{N}$ & $\%$ & $\mathbf{N}$ \\
\hline \multicolumn{9}{|c|}{ Level of experience in leadership and personnel management (yes=1) } \\
\hline - none & 0.02 & 191 & 0.01 & 87 & 0.02 & 104 & 0.15 & 88 \\
\hline - average practical experience & 0.37 & 191 & 0.28 & 87 & 0.45 & 104 & 0.47 & 88 \\
\hline - expert & 0.47 & 191 & 0.54 & 87 & 0.40 & 104 & 0.39 & 88 \\
\hline - professional & 0.15 & 191 & 0.17 & 87 & 0.13 & 104 & 0.00 & 88 \\
\hline - no answer & 0.00 & 191 & 0.00 & 87 & 0.00 & 104 & 0.00 & 88 \\
\hline \multicolumn{9}{|c|}{ Involvement in personnel selection (past 5 yrs.) (yes $=1$, multiple answers possible) } \\
\hline - none & 0.03 & 192 & 0.02 & 88 & 0.04 & 104 & 0.25 & 88 \\
\hline - pre-selection by application screening & 0.46 & 192 & 0.44 & 88 & 0.48 & 104 & 0.36 & 88 \\
\hline - interviews, expert function & 0.29 & 192 & 0.27 & 88 & 0.31 & 104 & 0.57 & 88 \\
\hline - interviews, hr function & 0.75 & 192 & 0.84 & 88 & 0.67 & 104 & 0.02 & 88 \\
\hline - other & 0.10 & 192 & 0.10 & 88 & 0.11 & 104 & 0.09 & 88 \\
\hline
\end{tabular}

Note:

Greyed cells: significant difference in proportion of respondents with respective experience between ME and CT determined based on Chi2-test (test statistics see Table A.1 in Appendix A).

Almost all HR decision makers have already participated in job interviews, mostly in an HR capacity in the past 5 years. $46 \%$ of them have also pre-selected candidates by application screening. In addition, $10 \%$ mention other activities in personnel selection such as running or developing assessment centres, recommending potential hires, or making the final decision. Of those who were involved in personnel selection, $65 \%$ were involved in more than 20 selection processes during the 5 years preceding the survey. We concluded that the responding HR decision makers are highly experienced in personnel management and personnel selection, although human resource management (HRM) in CT firms tends to be slightly less institutionalized compared with ME. The latter finding is, however, not surprising given that ME is a more established technology field than $\mathrm{CT}$, and is characterized by larger and more established companies on average (see results below).

\subsection{Current employer and career position (Module C)}

At the time of the survey, HR decision makers in ME work in firms who have their technological focus on mechanical engineering (36\%), electrical engineering (13\%), transportation and engines $(11 \%)$ and $\mathrm{ME}(8 \%)$. HR decision makers in CT come from firms with CT (17\%), electrical engineering (17\%) and mechanical engineering (14\%) as the main technology field. For technology experts, the distribution across technology fields displays some similarities, but is clearly more focused on transportation and engines (26\%).

We obtain responses from HR decision makers of firms of different sizes, ranging from two to 100,000 employees. Half of the respondents work in firms with less than 300 employees and only $10 \%$ work in firms with 5000 employees or more. The responding technology experts work in larger firms (median: 4450 employees). Hence, HR decision makers work in smaller firms compared with technology experts. For both groups, ME firms tend to be slightly larger than CT firms.

On average, HR decision makers have a tenure of 8.7 years, with average tenure being about 2 years (significantly) higher for HR decision makers in ME compared with their counterparts in CT. Again, this difference may well be caused by the maturity of the technology. 
Technology experts have been employed considerably longer at their current employer than the HR decision makers (17.6 years).

Most of the employers of our technology experts (90\%) as well as the majority of the employers of our HR decision makers in ME (60\%) have a separate HR department. Only about half of the employers of HR decision makers in CT have a separate HR department and for $40 \%$ of the employers, personnel decisions are taken by one or more board members. These differences are statistically significant (test statistics are displayed in Table A.1, Appendix A).

Most of the decision makers are currently working as HR managers (40\% on average, CT only $31 \%$ ) or as an employee in a HR department (39\%). Another $16 \%$ are part of the management board of the company. In addition, $7 \%$ hold another current position, e.g., assistant of the CEO, manager or employee in the R\&D department, or manager in controlling or general administration. Significantly fewer HR decision makers in CT work as HR mangers (31\%) compared with HR decision makers in ME $(50 \%)$.

Most firms (75\%) have recruited between 2 and 19 new employees in the past 5 years. Recruitment activity is somewhat higher in ME compared with CT firms, which might be a result of the larger average size of ME firms.

The responding firms are highly innovative: on average, they generated $35 \%$ of their turnover based on new products or services during the past 5 years.

Overall, $70 \%$ of the responding HR decision makers can be defined as "experienced in hightech recruitment" (results not reported in Table A.1 in Appendix): they have been involved at least three times in personnel selection processes within the past 5 years, and work in a company that generates at least $25 \%$ of turnover based on new products and services. The share of HR experts in high-tech recruitment is somewhat higher for HR decision makers in ME (72\%) compared with HR decision makers in CT (67\%), although the difference is not statistically significant. 


\subsection{Choice-based experiment (Module D)}

Table 5 shows the proportion of profiles with a certain candidate characteristic. In our randomized design, all candidate levels were presented with equal frequency. For attributes with two levels, such as professional background, each candidate characteristic appears in $50 \%$ of all profiles. For attributes with three levels, such as the motivation for the application, each candidate characteristic is presented in one third of all profiles. Table 5 shows that this is the case for both respondent groups; HR decision makers and technology experts.

Table 5: Proportion of candidate profiles chosen depending on candidate characteristics.

\begin{tabular}{|c|c|c|c|c|c|c|}
\hline \multirow[t]{2}{*}{ Candidate characteristic } & \multicolumn{2}{|c|}{$\begin{array}{l}\text { Proportion of } \\
\text { profiles with } \\
\text { candidate } \\
\text { characteristic } \\
\text { presented }\end{array}$} & \multicolumn{4}{|c|}{$\begin{array}{l}\text { Proportion of selected profiles ("best") } \\
\text { with candidate characteristic }\end{array}$} \\
\hline & HR & $\mathrm{TECH}$ & $\begin{array}{l}\text { HR } \\
\text { all }\end{array}$ & only ME & only CT & $\begin{array}{l}\text { TECH } \\
\text { all }\end{array}$ \\
\hline \multicolumn{7}{|l|}{ Professional background } \\
\hline engineering & 0.50 & 0.50 & 0.60 & 0.64 & 0.56 & 0.57 \\
\hline & 0.50 & 0.50 & 0.40 & 0.36 & 0.44 & 0.43 \\
\hline \multicolumn{7}{|l|}{ Job experience } \\
\hline rather specialized (“expert”) & 0.50 & 0.50 & 0.50 & 0.53 & 0.48 & 0.43 \\
\hline rather broad ("generalist") & 0.50 & 0.50 & 0.50 & 0.47 & 0.52 & 0.57 \\
\hline \multicolumn{7}{|l|}{ Special skill } \\
\hline creativity & 0.33 & 0.34 & 0.37 & 0.36 & 0.37 & 0.43 \\
\hline risk attitude & 0.33 & 0.33 & 0.22 & 0.22 & 0.22 & 0.12 \\
\hline analytical and systematic problem solving & 0.33 & 0.33 & 0.41 & 0.42 & 0.41 & 0.44 \\
\hline \multicolumn{7}{|l|}{ Main motivation for application } \\
\hline independent and autonomous working & 0.33 & 0.33 & 0.27 & 0.29 & 0.25 & 0.27 \\
\hline developing path-breaking technologies & 0.33 & 0.34 & 0.44 & 0.45 & 0.43 & 0.44 \\
\hline environmental protection and sustainability & 0.33 & 0.33 & 0.29 & 0.26 & 0.31 & 0.29 \\
\hline \multicolumn{7}{|l|}{ Previous patenting experience } \\
\hline no patent filed & 0.33 & 0.34 & 0.19 & 0.19 & 0.18 & 0.23 \\
\hline at least one patent filed (any field) & 0.33 & 0.33 & 0.33 & 0.34 & 0.31 & 0.35 \\
\hline at least one patent filed in ME/CT & 0.33 & 0.33 & 0.49 & 0.47 & 0.50 & 0.42 \\
\hline $\mathrm{N}$ & 5850 & 2670 & 1780 & 783 & 997 & 851 \\
\hline
\end{tabular}

Notes:

$\mathrm{HR}=\mathrm{HR}$ decision makers, $\mathrm{TECH}=$ technology experts, $\mathrm{ME}=$ mechanical elements, $\mathrm{CT}=$ clean technology.

Candidate characteristic more than proportionally prevalent among selected profiles.

The first two columns of Table 6 show how often a profile with the respective candidate level was chosen as the best-suited candidate. A level of candidate characteristics with two (three) levels was presented to the respondents in half (one third) of the choice sets. If a level of the characteristics has been selected in more than half (one third) of the preferred choice sets, this indicates that the respondents prefer this level over the other level(s) of the characteristic. On average, all respondents prefer candidates with an engineering background and a particular capacity for analytical thinking and systematic problem solving, candidates who are mainly motivated by the development of path-breaking technologies, and who have filed at least one patent in the relevant technology field. Candidates with a positive risk attitude, independent and autonomous working as main motivation for the application or no patents filed are the 
least preferred. Technology differences arise with respect to the experience of candidates: HR decision makers in ME prefer specialists, whereas HR decision makers in CT and technology experts prefer candidates with a broad background (generalists).

\subsection{Technology development and recruitment at respondents' current employer (Module E)}

Figure 3 illustrates the importance of technology development as well as the talent situation in firms where HR decision makers were employed at the time of the survey.

Figure 3: Agreement with statements on technology development and R\&D recruitment.

Percent of respondents who agree or strongly agree with statement.

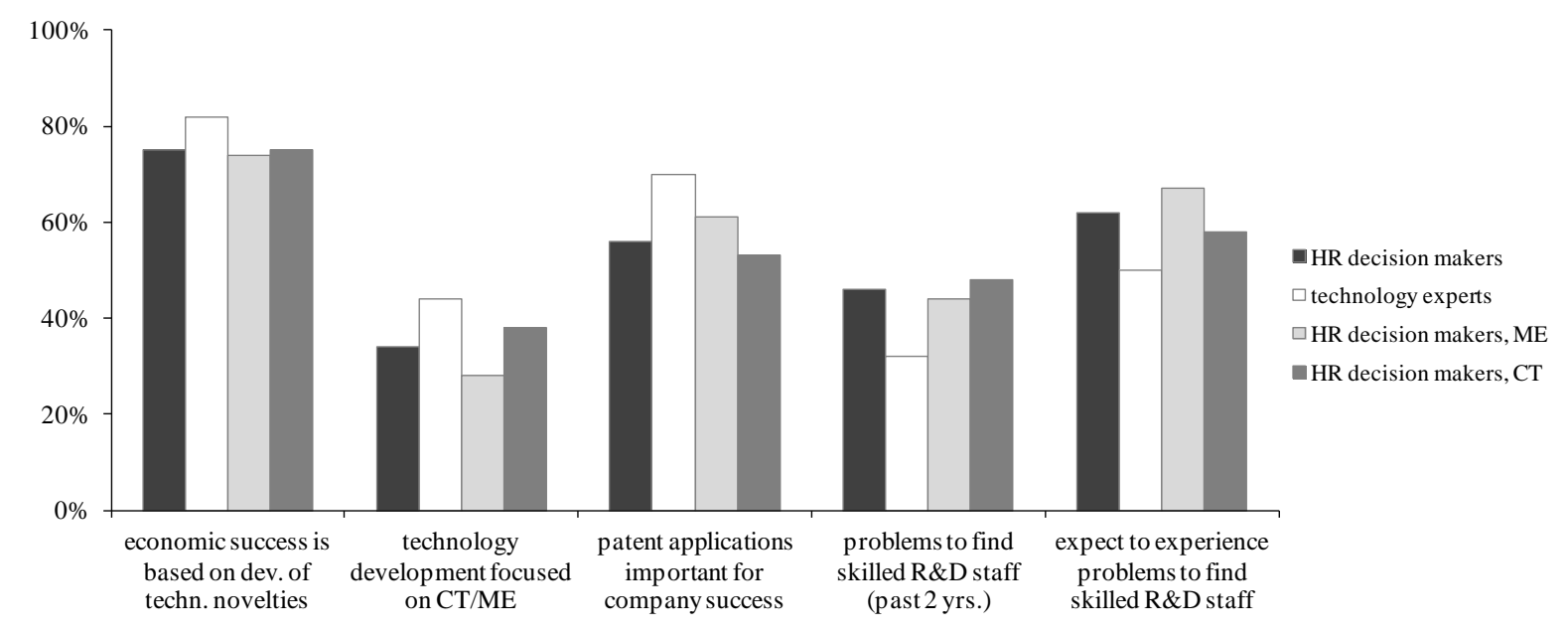

Notes:

Sample size between $\mathrm{N}=164$ and 165 for HR decision makers, $\mathrm{N}=72$ for HR decision makers in ME, between $\mathrm{N}=92$ and 93 for HR decision makers in CT and between $\mathrm{N}=78$ and 82 for technology experts, depending on the company characteristic covered by the respective survey question.

Three quarters of HR decision makers $(75 \%)$ agree with the statement that the economic success of their company is based on the development of technological novelties. In $34 \%$ of HR decision makers' firms, technology development is focused on ME or CT. Patent applications are important for company success in about $56 \%$ of cases. About $46 \%$ of respondents' firms experienced problems in finding skilled R\&D staff during the past 2 years, and $62 \%$ expected problems in filling $R \& D$ vacancies in the coming 5 years.

Notable technology differences arise only for the question of how far company success depends on technology development activities that are focused on ME (28\%) or CT (38\%). This difference is however not statistically significant. Compared with HR decision makers, technology experts agree significantly more with the statements on the importance of specialized technology development and patent applications for company success, and significantly less with the statements on the difficulty in finding skilled R\&D staff in the past and the future?

Our survey also contained a question about the channels a company uses for the recruitment of R\&D staff. This question was only administered to HR decision makers, and not to technology experts. The results are presented in Table A.1 in Appendix A. Almost all firms use advertisements in online media (96\%), receive unsolicited applications (98\%), and draw upon former interns or trainees (94\%) as sources for recruiting new R\&D staff.

\footnotetext{
${ }^{9}$ Difference in proportions significant at the $5 \%$ level according to Chi2-test for all statements mentioned.
} 
Advertisements in print media are only used by $87 \%$ of firms. Recommendations by R\&D or other employees already working in the firm are also a frequently used recruitment channel, whereas head hunters or personnel consultancy services $(80 \%)$ and career fairs $(69 \%)$ are the least used channels.

Table 6 displays frequencies of use for the different recruitment channels by firm size and technology field so as not to confound the effects of technology field and firm size (CT firms tend to be smaller than ME firms). Compared with large firms (84\%), small firms less frequently $(55 \%)$ participate in career fairs to recruit R\&D staff ${ }^{10}$.

In particular, technology differences arise in small firms: CT firms draw significantly less often on advertisements in print and online media, but use recommendations more frequently, particularly for non-R\&D employments. Recommendations by $R \& D$ staff also play a significantly more important role in large CT firms compared with large ME firms (both in smaller and larger CT firms). The fact that in CT firms, the use of personal networks for recruiting $\mathrm{R} \& \mathrm{D}$ staff is more important than conventional advertisements in print and online media are consistent with our findings that the HR function in CT firms is less institutionalized than ME firms (see Section 3.2).

Table 6: Frequency of use and success of $R \& D$ recruitment channels by firm size and technology field.

\begin{tabular}{lccccccccccc}
\hline & \multicolumn{3}{l}{ small firms } & \multicolumn{9}{c}{ large firms } \\
& ME & \multicolumn{2}{c}{ CT } & \multicolumn{3}{c}{$\begin{array}{c}\text { Chi2- } \\
\text { Test }\end{array}$} \\
& prop & $\mathrm{N}$ & prop & $\mathrm{N}$ & $\mathrm{pp}^{\mathrm{A}}$ & prop & $\mathrm{N}$ & prop & $\mathrm{N}$ & $\begin{array}{c}\text { Chi2- } \\
\text { Test } \\
\text { (p)A }\end{array}$ \\
\hline advertisements, print media & 0.97 & 31 & 0.75 & 55 & 0.01 & 0.95 & 39 & 0.88 & 34 & 0.30 \\
advertisements, online media & 1 & 31 & 0.89 & 55 & 0.06 & 1.00 & 40 & 1 & 34 &. \\
head-hunter & 0.84 & 31 & 0.7 & 54 & 0.16 & 0.8 & 40 & 0.88 & 34 & 0.34 \\
career fairs & 0.61 & 31 & 0.52 & 52 & 0.41 & 0.9 & 40 & 0.76 & 33 & $<0.10$ \\
unsolicited applications & 0.97 & 31 & 0.96 & 55 & 0.92 & 1.00 & 40 & 1.00 & 34 &. \\
former interns & 0.87 & 30 & 0.91 & 54 & 0.56 & 0.97 & 40 & 1.00 & 34 & 0.35 \\
recommendations, R\&D empl. & 0.74 & 31 & 0.82 & 55 & 0.40 & 0.85 & 40 & 0.97 & 34 & 0.08 \\
recommendations, other emp. & 0.74 & 31 & 0.89 & 55 & 0.07 & 0.90 & 40 & 0.94 & 34 & 0.52 \\
\hline
\end{tabular}

Notes:

${ }^{\mathrm{A}}$ Chi-Squared test on the equality of proportions $(\mathrm{p}<0.10|<0.05| 0.01$ indicates that proportion are significantly different at the $10 \%|5 \%| 1 \%$ level).

Greyed cells: significant difference in proportion between ME and CT.

\subsection{Values, attitudes, orientations, capabilities (Module F)}

In the last module, we administered a number of items and short tests on values, attitudes, orientations, and specific capabilities to the survey participants.

The attitude towards risk was evaluated based on a self-assessment ranging between 0 ("highly risk averse") and 10 ("highly risk seeking"). HR decision makers rate their attitude as 6.5 points on average. Technology experts are characterized by a similar risk-taking attitude (6.7 points on average).

The capacity for systematic problem solving is determined by administering the cognitive reasoning test (CRT) published by Frederick (2005) to the survey participants. The three-item

\footnotetext{
${ }^{10}$ Results not reported. Difference of proportions is significant at the $1 \%$ level according to the Chi2-test.
} 
short scale provides a simple measure for the cognitive problem solving style of a person. ${ }^{11}$ The respondents were presented with three puzzles that are designed so that an intuitive answer springs quickly to mind, but the correct answer is only obtained if respondents reflect more systematically on the puzzle. The more correct answers, the more systematically the respondent reflects on problems. People scoring low are assumed to employ a quick intuitive problem-solving style. To capture a strong tendency for systematic thinking, we create a dummy variable that takes a value corresponding to the number of CRT questions answered correctly; for example, the value was 3 if all three questions were answered correctly, and zero if all answers were wrong. On average, HR decision makers have 1.9 correct answers, whereas technology experts reach a significantly higher score of 2.5 correct answers $(\mathrm{p}=$ 0.00 , $t$-test on mean difference). This level is higher than all experimental groups used in the original study by Frederick (2005), where the best-performing group, students of the Massachusetts Institute of Technology, scored 2.18 on average. Again, there were no significant differences between the two technology fields.

Finally, we administered questions to the survey participants on environmental orientation, taken from a study by Kuckertz and Wagner (2010). Respondents received a set of five statements on general environmental issues and were asked to express their agreement on a scale from 1 ("I do not agree at all") to 5 ("I completely agree").

The great majority of HR decision makers agree or even strongly agree with the statements with respect to

- environmental problems being one of the biggest challenges for our society (88\%),

- the need for entrepreneurs and companies to take on a larger social responsibility (78\%),

- firms taking a leading role in the field of environmental protection (81\%), as well as

- corporate social responsibility being part of the foundations of each company (83\%).

However, only about a third of HR decision makers think that firms that are environmentally oriented have advantages in recruiting and retaining qualified employees, and that the environmental performance of a company will be considered increasingly by financial institutions (e.g., for credit and ratings). Only for this latter aspect, there are notable differences between HR decision makers in CT and ME: 44\% of HR decision makers in CT compared with $20 \%$ in ME are convinced that environmental performance will matter to financial institutions in the future. Technology experts display very similar environmental orientations, but with a significantly higher agreement with almost all statements, except the statement that environmental performance will matter to financial institutions in the future, where the agreement is significantly lower (Chi2-test on differences in proportions, test statistics not reported).

A second, more extensive set of 13 statements on environmental issues first used by Scherhorn et al. (2012) was only administered to technology experts. The statement that is qualified correct or absolutely correct by most of the technology experts (85\%) is that "one should not buy products from firms that evidently act ecologically harmful even if that means to deny oneself certain things". The statement "To carry my purchases I rather buy a plastic bag than taking my own purchasing bag with me" receives least consent $(3 \%)$. These exemplary results underline the previous results that the majority of technology experts have an environmental-friendly mindset. Detailed results are displayed in Appendix A, Table A.2.

\footnotetext{
${ }^{11}$ Cognitive problem solving style is classified based on two cognitive processes (Kahnemann and Frederick, 2002). If so-called system 1 processes are activated, they lead to spontaneous decisions and are "unaffected by intellect, alertness [...] or difficulty of the [...] problem" (Frederick 2005, p. 26). However, system 2 processes lead to cognitive activation and concentration.
} 


\section{Estimating hiring preferences}

In this section, we investigate which aspects HR decision makers in each technology field value most.

\subsection{Estimation strategy}

Our estimation strategy for the hiring preferences is very similar to the empirical model suggested by Fischer and Henkel (2013), who split each best-worst choice of respondents into two choice sets ("exploded model", according to Beggs et al., 1981; Chapman and Staelin, 1982) and subsequently ran a mixed logit regression model. The mixed logit model combines multinomial and conditional logit.

After splitting the choice sets, the first choice set (new choice set ID $=1$ in Table 9) comprises three candidates. Here the candidate evaluated as the best (most preferred candidate) by the respondents out of the three candidates displayed is the selected choice. The second choice set (new choice set ID $=2$ in Table 9) only contains the remaining two candidates, and the second-best candidate (the one that is not marked as "worst (least preferred candidate)" in the original choice task) is marked as the selected choice. The splitting procedure is illustrated in Table 7:

Table 7: Splitting best-worst choices into two choice sets.

Best-worst-choice (one choice set, raw data)

\begin{tabular}{|l|l|l|l|l|}
\hline respondent ID & choice set ID & alternative & $\begin{array}{l}\text { most preferred } \\
\text { candidate } \\
(\text { yes=1) }\end{array}$ & $\begin{array}{l}\text { least preferred } \\
\text { candidate } \\
\text { (yes=1) }\end{array}$ \\
\hline 1 & 1 & 1 & 0 \\
\hline 1 & 1 & A & 0 & 0 \\
\hline 1 & 1 & B & 0 & 1 \\
\hline
\end{tabular}

After splitting into two choice sets

\begin{tabular}{|c|c|c|c|c|c|}
\hline respondent ID & $\begin{array}{l}\text { old } \\
\text { choice } \\
\text { set ID } \\
\end{array}$ & $\begin{array}{l}\begin{array}{l}\text { new } \\
\text { choice } \\
\text { set ID }\end{array} \\
\end{array}$ & alternative & $\begin{array}{l}\text { preferred } \\
\text { candidate } \\
(\text { yes }=1)\end{array}$ & \\
\hline 1 & 1 & 1 & $\mathrm{~A}$ & 1 & \multirow{3}{*}{ best choice } \\
\hline 1 & 1 & 1 & $\mathrm{~B}$ & 0 & \\
\hline 1 & 1 & 1 & $\mathrm{C}$ & 0 & \\
\hline 1 & 1 & 2 & $\mathrm{~B}$ & 1 & \multirow{2}{*}{$\begin{array}{l}\text { second-best } \\
\text { choice }\end{array}$} \\
\hline 1 & 1 & 2 & $\mathrm{C}$ & 0 & \\
\hline
\end{tabular}

Hence, 20 choices are obtained per respondent: 10 choices out of three alternative candidates and 10 choices out of two alternative candidates.

Fischer and Henkel (2013, p. 331) highlight that with repeated choices-here additionally with exploded choice sets-the assumption that the error terms of each respondent's choice of candidates are independent and identically distributed (IID) may be violated.

In particular, respondents who attach great importance to one candidate in a certain choice set are also likely to attach great importance to similar candidates in other choice sets. In this context, the appropriate econometric tool is a mixed logit estimation, as it does not need the IID assumption, whereas conditional logit estimators could be biased when the IID assumption is violated.

Each candidate presented to our respondents is described by five competence dimensions ("attributes") with two or three specific characteristics each ("levels"), as described in Section 3.2. We dummy coded all characteristics, so that the estimated coefficients indicate the deviation from the respective reference value we set in the regression models. For attributes 
with three levels, we used the level with the assumed intermediate utility as the reference level to interpret the preference orders and their significance compared with other attribute levels.

Revel and Train (1998) suggest a model for such repeated choice situations where respondents choose between $J$ alternatives in each of $T$ choice situations ${ }^{12}$ that we describe as follows.

The utility, $U$, that decision maker $n$ obtains from alternative $j$ in choice situation $t$ is $U_{n j t}=$ $\beta_{n} x_{n j t}+\varepsilon_{n j t}$, where $x_{n j t}$ is a vector of the observed variables (the characteristics in the profiles presented), and $\beta$ is an unobserved coefficient vector for each decision maker, which varies in the population with density $f\left(\beta_{n} \mid \theta\right)$. Note that the parameter vector, $\beta_{n}$, represents decision maker $n$ 's tastes and that these tastes vary between people; mixed logit allows for "random taste variation" between decision makers. The goal of the regression is to estimate the population parameters, $\theta$, of the distribution of $\beta_{n}$ (i.e. mean and covariance) that describe the distribution of individual parameters. Closely related to this, mixed logit allows unrestricted substitution patterns between alternatives because it does not exhibit the restrictive independence of the irrelevant alternatives (IIA) property that logit uses.

$\varepsilon_{n j t}$ is an unobserved random term that is the distributed IID extreme value and that is independent of $\beta_{n}$ and $x_{n j t}$. Conditional on $\beta_{n}$, the probability that person $n$ chooses alternative $i$ in period $t$ is

$$
L_{n i t}\left(\beta_{n}\right)=\frac{e^{\beta_{n} x_{n i t}}}{\sum_{j} e^{\beta_{n} x_{n i t}}} .
$$

The unconditional probability can then be obtained by integrating the conditional probabilities over all possible values of $\beta_{n}$,

$$
Q_{n i t}(\theta)=\int L_{n i t}\left(\beta_{n}\right) f\left(\beta_{n} \mid \theta\right) d \beta_{n},
$$

which depends on the distributional parameter $\theta$. As we have a sequence of observed choices, we must determine the probability of decision maker $n$ 's observed sequence of choices, which is (conditional on $\beta_{n}$ ) the product of standard logits

$$
S_{n}\left(\beta_{n}\right)=\prod_{t} L_{n i(n, t) t}\left(\beta_{n}\right) .
$$

The unconditional probability for the sequences of choices is then

$$
P_{n}(\theta)=S_{n}\left(\beta_{n}\right) f\left(\beta_{n} \mid \theta\right) d \beta_{n} .
$$

As the $\log$-likelihood function $L L(\theta)=\sum_{n=1}^{N} \ln P_{n}(\theta)$, which must be maximised, does not have a closed form solution (Fischer and Henkel, 2013, p. 332), we use the simulation procedure proposed by Revelt and Train (1998) and implemented by Hole (2007) in STATA (mixlogit command).

Further details on the specifications of mixed logit models for repeated choices are also described by Hole (2007) and by Fischer and Henkel (2013, p. 331-332).

\footnotetext{
${ }^{12}$ In our case, after splitting the best-worst choice set into two separate choice sets, we have 10 choice situations with 3 and 10 choice situations with 2 alternatives, respectively.
} 


\subsection{Results}

\subsubsection{Hiring preferences}

Table 8 provides mixed logit estimates for the hiring preferences of HR decision makers and technology experts. As explained in Section 4.1, the model takes into account that preferences may differ across respondents and coefficients may be correlated. More concretely, previous patenting experience is specified as a fixed-effects coefficient, whereas the preferences for the other four attributes (professional background, job experience, special skill, and main motivation for application) are assumed to vary across respondents. A likelihood ratio test for the joint significance of the standard deviations of the estimated coefficients is highly significant for all models in Table 8 , indicating that standard deviations are not jointly equal to zero (results not reported).

Table 8: Mixed logit models, correlated coefficients.

\begin{tabular}{|c|c|c|c|c|}
\hline & $\begin{array}{c}\text { HR decision } \\
\text { makers } \\
\text { (1a) }\end{array}$ & $\begin{array}{c}\text { Technology } \\
\text { experts } \\
(2 \mathbf{a}) \\
\end{array}$ & $\begin{array}{c}\text { HR decision } \\
\text { makers, ME } \\
(3 a)\end{array}$ & $\begin{array}{c}\text { HR decision } \\
\text { makers, CT } \\
(4 \mathbf{a})\end{array}$ \\
\hline \multicolumn{5}{|c|}{ Previous patenting experience (reference: patents in other technology field) } \\
\hline no patents ${ }^{\mathrm{A}}$ & $\begin{array}{c}-0.984 * * * \\
(0.0707)\end{array}$ & $\begin{array}{c}-0.852 * * * \\
(0.107)\end{array}$ & $\begin{array}{l}-1.171 * * * \\
(0.125)\end{array}$ & $\begin{array}{c}-0.909 * * * \\
(0.0947)\end{array}$ \\
\hline patents in same field ${ }^{\mathrm{A}}$ & $\begin{array}{c}0.811 * * * \\
(0.0686)\end{array}$ & $\begin{array}{c}0.580 * * * \\
(0.107)\end{array}$ & $\begin{array}{c}0.729 * * * \\
(0.119)\end{array}$ & $\begin{array}{c}0.945 * * * \\
(0.0930)\end{array}$ \\
\hline \multicolumn{5}{|c|}{ Professional background (reference: natural sciences) } \\
\hline engineering & $\begin{array}{c}0.596 * * * \\
(0.0798)\end{array}$ & $\begin{array}{c}0.598 * * * \\
(0.0901)\end{array}$ & $\begin{array}{c}0.803 * * * \\
(0.141)\end{array}$ & $\begin{array}{c}0.317 * * * \\
(0.0941)\end{array}$ \\
\hline \multicolumn{5}{|c|}{ Job experience (reference: specialist) } \\
\hline generalist & $\begin{array}{c}-0.131 \\
(0.0835)\end{array}$ & $\begin{array}{c}0.294 * * * \\
(0.111)\end{array}$ & $\begin{array}{c}-0.299 * * \\
(0.147)\end{array}$ & $\begin{array}{c}-0.0736 \\
(0.116)\end{array}$ \\
\hline \multicolumn{5}{|c|}{ Special skill (reference: creativity) } \\
\hline positive risk attitude & $\begin{array}{c}-0.927 * * * \\
(0.0965)\end{array}$ & $\begin{array}{l}-1.960 * * * \\
(0.186)\end{array}$ & $\begin{array}{c}-1.048 * * * \\
(0.194)\end{array}$ & $\begin{array}{c}-0.947 * * * \\
(0.147)\end{array}$ \\
\hline analytical thinking & $\begin{array}{c}0.295 * * * \\
(0.0805)\end{array}$ & $\begin{array}{l}0.0153 \\
(0.166)\end{array}$ & $\begin{array}{l}0.516 * * * \\
(0.151)\end{array}$ & $\begin{array}{l}0.230 * * \\
(0.110)\end{array}$ \\
\hline \multicolumn{5}{|c|}{ Main motivation for application (reference: independent and autonomous working) } \\
\hline technology development & $\begin{array}{c}0.959 * * * \\
(0.0973)\end{array}$ & $\begin{array}{c}0.939 * * * \\
(0.149)\end{array}$ & $\begin{array}{c}0.922 * * * \\
(0.210)\end{array}$ & $\begin{array}{l}0.954 * * * \\
(0.122)\end{array}$ \\
\hline environment + sustainability & $\begin{array}{c}0.142 \\
(0.0988) \\
\end{array}$ & $\begin{array}{l}0.0963 \\
(0.162) \\
\end{array}$ & $\begin{array}{l}-0.444 \\
(0.451) \\
\end{array}$ & $\begin{array}{c}0.520 * * * \\
(0.137)\end{array}$ \\
\hline Observations & 8905 & 4255 & 3915 & 4990 \\
\hline
\end{tabular}

Notes:

Standard errors in parentheses, $* * * \mathrm{p}<0.01, * * \mathrm{p}<0.05, * \mathrm{p}<0.1$

${ }^{\mathrm{A}}$ Variables with fixed coefficients, all other variables with random coefficients.

The results show that on average, HR decision makers prefer candidates with patenting experience (if possible technology specific), an engineering background, analytical thinking skills, and a strong orientation towards developing path-breaking technologies. Furthermore, if they had to choose between candidates who are motivated by independent autonomous working or by environmental protection and sustainability, they prefer, on average, the former. A positive risk attitude is least preferred compared with the other two special skills (i.e. creativity and analytical thinking). With respect to the type of previous job experience (generalist vs. specialist), only technology experts have a preference for generalists.

Running separate models for HR decision makers in ME and in CT, we find technologyspecific hiring preferences with respect to job experience and the main motivation. 
- $\quad$ HR decision makers in ME prefer specialists over generalist, whereas for HR decision makers in CT, we find no clear preference between specialists and generalists.

- HR decision makers in CT clearly prefer candidates with an orientation towards environmental protection and sustainability over candidates who are motivated by the opportunity of independent and autonomous work, whereas for HR decision makers in ME, candidates motivated by independent and autonomous work and candidates with an environmental and sustainability orientation have a similar utility.

To ensure that our results are not driven by methodological artefacts, we conducted a number of robustness checks (Appendix D). Estimating conventional logit models only for the bestchoices yields very similar results (Table D.1). ${ }^{13}$ We also estimated the models from Table 8 for the best and the second best choice separately. When looking at best choices only (Table D.2), the results remain robust, again. Looking at second-best choices, some of the formerly significant effects (e.g., engineering background for HR decision makers in CT, job experience for technology experts and HR decision makers in ME) now remain insignificant, but still point in the same direction. We explain this loss in significance by the fact that, when pre-screening candidates, respondents focus their attention on the best candidate, and have a less clear-cut preference order for the second-best and the least-best candidate.

Finally, we run the CT regressions separately for firms with and without EPO patents, to make sure that the differences in hiring preferences between CT and ME are not driven by our sampling procedure. As described earlier, the CT sample contains firms with and without EP patents, whereas the ME sample only contains companies that filed at least one EP patent. The results (Table D.4, Appendix D) show that the only difference in hiring preferences between patenting and non-patenting CT firms is that non-patenting firms prefer candidates with outstanding analytical thinking skills to candidates with outstanding creative skills, whereas patenting CT firms are indifferent with respect to these two characteristics. However, this difference does not affect the results of our comparative analysis provided in Table 8, because analytical thinking skills were not among the technology-specific characteristics.

From the results in Table 8, we are able to calculate the relative importance of each of the five candidate's competences for respondents' preferences. The relative importance of a candidate competence is computed as the attribute utility range divided by the total utility range (Orme 2010, p.79f.). This represents the difference between the level with the highest and the level with the lowest utility within one attribute, divided by the total utility range, which is the sum of attribute utility ranges across all attributes (Orme 2010, p. 79f.). Table 9 displays the relative importance of each of the five candidate competences.

HR decision makers attribute the highest importance for pre-interview candidate screening to previous patenting success. This is particularly true for HR decision makers in CT. In contrast, technology experts see special skills such as analytical thinking, creativity, or risk attitude as the most relevant selection criteria. The breadth of previous job experience and educational background are the least relevant dimensions for both respondent groups, whereas main motivation for the job application is of medium importance for both groups.

\footnotetext{
${ }^{13}$ Similarly, following the robustness check for mixed logit models suggested by Cameron and Trivedi (2005, p. 39f), the results of conditional logit models that are commonly used to estimate the random coefficients, and multinomial logit models that are suited to estimating fixed coefficients yield similar results (results not reported).
} 
Table 9: Relative importance of candidate attributes.

\begin{tabular}{lcccc}
\hline & $\begin{array}{c}\text { HR decision } \\
\text { makers }\end{array}$ & $\begin{array}{c}\text { Technology } \\
\text { experts }\end{array}$ & $\begin{array}{c}\text { HR decision } \\
\text { makers, ME }\end{array}$ & $\begin{array}{c}\text { HR decision } \\
\text { makers, CT }\end{array}$ \\
\hline Previous patenting experience & $39 \%$ & $28 \%$ & $32 \%$ & $48 \%$ \\
Professional background & $13 \%$ & $12 \%$ & $14 \%$ & $8 \%$ \\
Job experience & $3 \%$ & $6 \%$ & $5 \%$ & $2 \%$ \\
Special skill & $27 \%$ & $38 \%$ & $26 \%$ & $31 \%$ \\
Main motivation for application & $18 \%$ & $16 \%$ & $23 \%$ & $11 \%$ \\
\hline
\end{tabular}

\section{Discussion and Conclusions}

The research objective of this explorative report is to investigate which kind of educational prerequisites, expertise, and specific skills make a candidate attractive for firms in CT and ME that are searching for new R\&D workers who will be critical for invention success. We examine the hiring preferences of HR experts and technology experts based on a choice-based experiment, mirroring the stage of the selection process where candidates are pre-selected based on résumé screening.

The report is based on a new survey and experimental data from HR decision makers in 194 German high-tech firms, and on 89 technology experts in CT and ME who were asked to provide résumé evaluations for fictitious candidates.

HR decision makers and technology experts from firms of different sizes and in different technological fields participated in our survey. The responding firms are highly innovative and recruit new employees on a regular basis. About half of the firms already report that they experience problems in finding skilled R\&D staff, and two thirds expect to do so in the near future.

In the majority of companies, HR is handled in a separate department. Overall, our respondents, particularly HR decision makers, have a high level of professional experience in general leadership, personnel management, and personnel selection. Many of the HR decision makers are working as HR managers or as employees in an HR department, and have been recently involved in personnel selection processes. Almost all of them have already participated in job interviews, and half have already pre-selected candidates by application screening.

With respect to many aspects covered in the survey, we find that HR is clearly less institutionalized in CT firms compared with ME firms. For example, HR decision makers in CT evaluate themselves as being somewhat less experienced in HRM and they are less frequently employed directly in the HR department, if there is an HR department at all. Furthermore, CT firms more frequently use personal networks for recruiting new R\&D workers. Beyond the professional expertise in HR, HR decision makers show considerable ability for systematic problem solving, even though they do not reach the outstanding average score that we find for technology experts.

Finally, all respondents have values oriented towards environmental protection and sustainability, albeit they do not believe that companies can reap economic benefits from being environmentally orientated, e.g., with respect to recruiting and retaining qualified employees or for bank lending and financial ratings.

Estimating hiring preferences based on a mixed logit model that allows us to deal with repeated choices shows that HR decision makers prefer candidates with patenting experience 
(if possible technology specific), an engineering background, analytical thinking skills, and a strong orientation to developing path-breaking technologies.

We furthermore show that there is no one-size-fits-all candidate that is equally preferred in both technology fields: HR decision makers prefer specialists rather than generalists in ME, and HR decision makers in CT attach special importance to a candidate's orientation towards environmental concerns and sustainability.

Our report provides new insights into the early stages of the recruitment process in general, and more specifically into the hiring of R\&D workers in high-tech firms. For example, it sheds light on the question of which education, work experience, and additional skills German high-tech firms in $\mathrm{CT}$ and $\mathrm{ME}$ value most when filling vacant positions in their $\mathrm{R} \& \mathrm{D}$ departments. 


\section{References}

Abbey, A., Dickson, J. (1983). R\&D work climate and innovation in semiconductors. The Academy of Management Journal, 26(2), 362-368.

Addelman, S. (1962). Symmetrical and asymmetrical fractional factorial plans. Technometrics, 4, 47-58.

Amabile, T., R. Conti, H. Coon, J. Lazenby, and M. Herron (1996). Assessing the Work Environment for Creativity. Academy of Management Journal, 39(5), 1154-1184.

Amabile, T. (1997). Motivating creativity in organizations: On doing what you love and loving what you do. California Management Review, 40(1), 39-58.

Anseel, F., Lievens, F., Schollaert, E., Choragwicka, B. (2010). Response rates in organizational science, 1995-2008: A meta-analytic review and guidelines for survey researchers. Journal of Business and Psychology, 25(3), 335-349.

Beggs, S., Cardell, S., Hausman, J. (1981). Assessing the potential demand for electric cars. Journal of Econometrics, 17(1), 1-19.

Chapman, R., Staelin, R. (1982). Exploiting rank ordered choice set data within the stochastic utility model. Journal of Marketing Research, 288-301.

Cameron, C., Trivedi, P. (2005). Microceconometrics: Methods and applications, Cambridge: Cambridge University Press.

Cole, M., Feild, H., Giles, W. (2003). What can we uncover about applicants based on their resumes? A field study. Applied HRM Research, 8(2), 51-62.

Cole, M., Feild, H., Stafford, J. (2005). Validity of resumé reviewers' inferences concerning applicant personality based on resumé evaluation. International Journal of Selection and Assessment, 13(4), 321-324.

Cole, M., Rubin, R., Feild, H., Giles, W. (2007). Recruiters' perceptions and use of applicant résumé information: Screening the recent graduate. Applied Psychology, 56(2), 319343.

Cole, M., Feild, H., Giles, W., Harris, S. (2009). Recruiters' inferences of applicant personality based on resume screening: Do paper people have a personality? Journal of Business Psychology, 24(1), 5-18.

Chrzan, K. (1994). Three kinds of order effects in choice-based conjoint analysis. Marketing Letters, 5(2), 165-172.

Chrzan, K., Orme, B. (2000). An overview and comparison of design strategies for choicebased conjoint analysis. Sawtooth Software Research Paper Series, online available at http://www.sawtoothsoftware.com/download/techpap/desgncbc.pdf, accessed on November 28, 2014.Dipboye, R., Fontenelle, G., Garner, K. (1984). Effects of previewing the application on interview process and outcomes. Journal of Applied Psychology, 69(1), 118-128.

Elrod, T., Louviere, J., Davey, K. (1992). An empirical comparison of ratings-based and choice-based conjoint models. Journal of Marketing Research, 29(3), 368-377.

Espacenet (2012). Y-classification for cleantech, online available at http://worldwide.espacenet.com/eclasrch?classification=ecla\&locale=en_EP\&ECLA=y 02, accessed on May 5, 2012.

Fischer, T., Henkel, J. (2013). Complements and substitutes in profiting from innovation - A choice experimental approach. Research Policy, 42, 326-339. 
Frederick, S. (2005). Cognitive reflection and decision making. Journal of Economic Perspectives, 19(4), 25-42.

Frosch, K., Harhoff, D., Hoisl, K., Steinle, C., Zwick, T. (2014a). Clean technology innovations in Germany: Human capital accumulation under heterogeneous knowledge inputs - Data and methodology report, mimeo.

Frosch, K., Harhoff, D., Hoisl, K., Steinle, C., Zwick, T. (2014b). Individual determinants of inventor productivity: Report and preliminary results with evidence from linked human capital and patent data, ZEW Discussion Paper 15-001, Mannheim.

Green, P., Srinivasan, V. (1990). Conjoint analysis in marketing: New developments with implications for research and practice. Journal of Marketing, 54(4), 3-19.

Gruber, M., Harhoff, D., Hoisl, K. (2013). Knowledge recombination across technological boundaries: Scientists versus engineers. Management Science, 59(4), 837-851.

Harhoff, D., Hoisl, K. (2010). Patente in mittelständischen Unternehmen - Eine empirische Studie des Instituts für Innovationsforschung, Technologiemanagement und Entrepreneurship, München.

Hebda, J., Vojak, B., Griffin, A., Price, R. (2012). Motivating and demotivating technical visionaries in large corporations: A comparison of perspectives. R\&D Management, 42(2), 101-119.

Hole, A. (2007). Fitting mixed logit models by using maximum simulated likelihood. Stata Journal, 7(3), 388-401.

Hsu, D., Ziedonis, R. (2008). Patents as quality signals for entrepreneurial ventures. Academy of Management Proceedings, 2008(1), 1-6.

Huber, J., Zwerina, K. (1996). The importance of utility balance in efficient choice designs. Journal of Marketing Research, 33(3), 307-317.

Kahneman, D., Frederick, S. (2002). Representativeness revisited: Attribute substitution in intuitive judgment. In: Gilovich, T., Griffin, D., Kahneman, D. (eds.), Heuristics and biases: The psychology of intuitive judgment, New York: Cambridge University Press, 49-81.

Knouse, S. (1994). Impressions of the resume: The effects of applicant education, experience, and impression management. Journal of Business and Psychology, 9(1), 33-45.

Kuckertz, A., Wagner, M. (2010). The influence of sustainability orientation on entrepreneurial intentions - Investigating the role of business experience. Journal of Business Venturing, 25(5), 524-539.

Louviere, J., Woodworth, G. (1983). Design and analysis of simulated consumer choice or allocation experiments: An approach based on aggregate data. Journal of Marketing Research, 350-367.

Orme, B. (2009). Fine-tuning CBC and adaptive CBC questionnaires, Sawtooth Software Research Paper Series, online available at http://www.sawtoothsoftware.com/download/techpap/finetune.pdf, accessed on November 28, 2014.

Orme, B. (2010). Getting started with conjoint analysis. Strategies for product design and pricing research, 2nd ed., Madison: Research Publishers.

Revelt, D., Train, K. (1998). Mixed logit with repeated choices: Households' choices of appliance efficiency level. Review of Economics and Statistics, 80(4), 647-657. 
Roberts, E., Fusfeld, A. (1981). Staffing the innovative technology-based organization. Sloan Management Review, 22(3), 19-34.

Sawtooth (2013). The CBC system for choice-based conjoint analysis. Sawtooth Software Technical Papers Series, online available at https://sawtoothsoftware.com/download/techpap/cbctech.pdf, accessed on October 27, 2014.

Scherhorn, G., Haas, H., Hellenthal, F., Seibold, S. (2012). Naturverträglichkeit. In: Glöckner-Rist, A. (Hrsg.), Zusammenstellung sozialwissenschaftlicher Items und Skalen, ZIS Version 15.00, Bonn: GESIS.

Schmoch, U. (2008). Concept of a technology classification for country comparisons: Final report to the World Intellectual Property Organisation (WIPO). Fraunhofer Institute for Systems and Innovation Research, online available at http://www.wipo.int/export/sites/www/ipstats/en/ statistics/patents/pdf/wipo_ipc_technology.pdf, accessed on August 23, 2014.

Spence, M. (1973). Job market signalling. The Quarterly Journal of Economics, 87(3), 355374.

Veefkind, V., Hurtado-Albir, J., Angelucci, S., Karachalios, K., Thumm, N. (2012). A new EPO classification scheme for climate change mitigation technologies. World Patent Information, 34(2), 106-111. 


\section{Appendix A: Descriptive Statistics}

Table A.1: Descriptive indicators for HR decision makers in ME and CT firms.

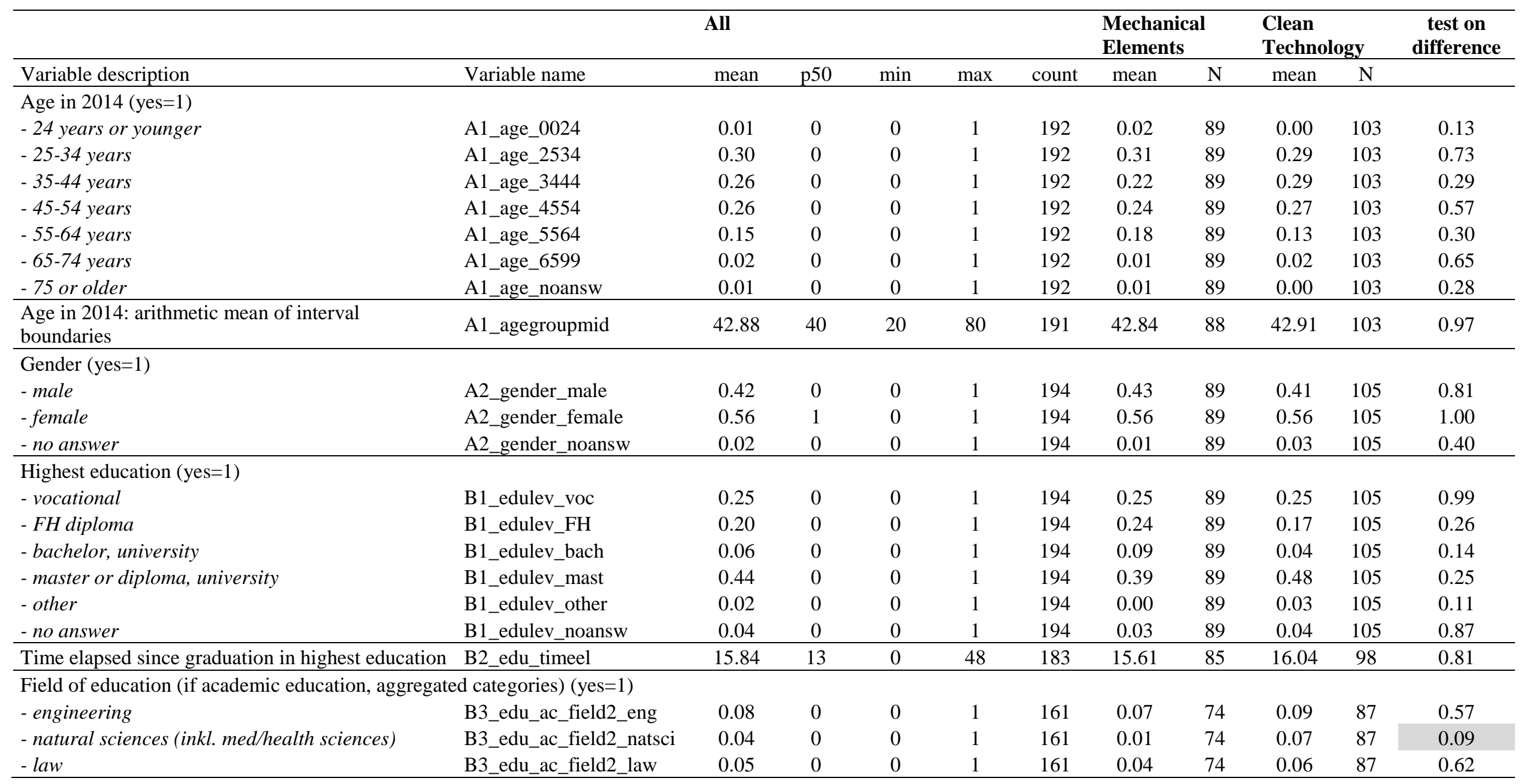




\begin{tabular}{|c|c|c|c|c|c|c|c|c|c|c|c|}
\hline \multirow[b]{2}{*}{ Variable description } & \multicolumn{4}{|c|}{ All } & \multirow[b]{2}{*}{$\max$} & \multirow[b]{2}{*}{ count } & \multicolumn{2}{|c|}{$\begin{array}{l}\text { Mechanical } \\
\text { Elements }\end{array}$} & \multicolumn{2}{|c|}{$\begin{array}{l}\text { Clean } \\
\text { Technology }\end{array}$} & \multirow[t]{2}{*}{$\begin{array}{c}\text { test on } \\
\text { difference }\end{array}$} \\
\hline & Variable name & mean & $\mathrm{p} 50$ & $\min$ & & & mean & $\mathrm{N}$ & mean & $\mathrm{N}$ & \\
\hline - economics and business & B3_edu_ac_field2_bus & 0.53 & 1 & 0 & 1 & 161 & 0.53 & 74 & 0.54 & 87 & 0.87 \\
\hline - social sciences (incl. arts, languages) & B3_edu_ac_field2_soc & 0.13 & 0 & 0 & 1 & 161 & 0.16 & 74 & 0.10 & 87 & 0.27 \\
\hline - other & B3_edu_ac_field2_other & 0.07 & 0 & 0 & 1 & 161 & 0.11 & 74 & 0.05 & 87 & 0.13 \\
\hline - no answer & B3_edu_ac_field2_noansw & 0.09 & 0 & 0 & 1 & 161 & 0.08 & 74 & 0.09 & 87 & 0.81 \\
\hline \multicolumn{12}{|c|}{ Field of education (if vocational education, aggregated categories) (yes=1) } \\
\hline - handicraft & B3_edu_voc_field_hand & 0.00 & 0 & 0 & 0 & 32 & 0.00 & 14 & 0.00 & 18 & . \\
\hline - technical & B3_edu_voc_field_tech & 0.03 & 0 & 0 & 1 & 32 & 0.00 & 14 & 0.06 & 18 & 0.37 \\
\hline - natural sciences & B3_edu_voc_field_nat & 0.00 & 0 & 0 & 0 & 32 & 0.00 & 14 & 0.00 & 18 & . \\
\hline - social & B3_edu_voc_field_soc & 0.00 & 0 & 0 & 0 & 32 & 0.00 & 14 & 0.00 & 18 & . \\
\hline - commercial & B3_edu_voc_field_comm & 0.94 & 1 & 0 & 1 & 32 & 1.00 & 14 & 0.89 & 18 & 0.20 \\
\hline - other & B3_edu_voc_field_other & 0.00 & 0 & 0 & 0 & 32 & 0.00 & 14 & 0.00 & 18 & . \\
\hline - no answer & B3_edu_voc_field_noansw & 0.03 & 0 & 0 & 1 & 32 & 0.00 & 14 & 0.06 & 18 & 0.37 \\
\hline HRM specialization in education (yes=1) & B4_hrm_study & 0.48 & 0 & 0 & 1 & 185 & 0.49 & 87 & 0.46 & 98 & 0.63 \\
\hline \multicolumn{12}{|l|}{ Leadership/HRM experience (yes=1) } \\
\hline - none & B5_hrm_exp_none & 0.02 & 0 & 0 & 1 & 191 & 0.01 & 87 & 0.02 & 104 & 0.67 \\
\hline - average practical experience & B5_hrm_exp_average & 0.37 & 0 & 0 & 1 & 191 & 0.28 & 87 & 0.45 & 104 & 0.01 \\
\hline - expert & B5_hrm_exp_expert & 0.47 & 0 & 0 & 1 & 191 & 0.54 & 87 & 0.40 & 104 & 0.06 \\
\hline - professional & B5_hrm_exp_prof & 0.15 & 0 & 0 & 1 & 191 & 0.17 & 87 & 0.13 & 104 & 0.36 \\
\hline - no answer & B5_hrm_exp_noansw & 0.00 & 0 & 0 & 0 & 191 & 0.00 & 87 & 0.00 & 104 & . \\
\hline \multicolumn{12}{|c|}{$\begin{array}{l}\text { Involvement in personnel selection (past } 5 \text { yrs.) } \\
\text { (yes=1, multiple answers possible) }\end{array}$} \\
\hline - none & B6_pers_sel_none & 0.03 & 0 & 0 & 1 & 192 & 0.02 & 88 & 0.04 & 104 & 0.53 \\
\hline - preselection by application scr & B6_pers_sel_cv & 0.46 & 0 & 0 & 1 & 192 & 0.44 & 88 & 0.48 & 104 & 0.60 \\
\hline - interviews, expert function & B6_pers_sel_int_exp & 0.29 & 0 & 0 & 1 & 192 & 0.27 & 88 & 0.31 & 104 & 0.60 \\
\hline - interviews, hr function & B6_pers_sel_int_hr & 0.75 & 1 & 0 & 1 & 192 & 0.84 & 88 & 0.67 & 104 & 0.01 \\
\hline - other & B6_pers_sel_oth & 0.10 & 0 & 0 & 1 & 192 & 0.10 & 88 & 0.11 & 104 & 0.94 \\
\hline \multicolumn{12}{|c|}{ Frequency of involvement in personnel selection (past 5 yrs., only if involvement at all) (yes=1) } \\
\hline - 1-2 times & B7_pers_sel_freq_1_2 & 0.02 & 0 & 0 & 1 & 186 & 0.01 & 86 & 0.02 & 100 & 0.65 \\
\hline - 3-9 times & B7_pers_sel_freq_3_9 & 0.16 & 0 & 0 & 1 & 186 & 0.12 & 86 & 0.20 & 100 & 0.12 \\
\hline - 10-20 times & B7_pers_sel_freq_10_20 & 0.18 & 0 & 0 & 1 & 186 & 0.16 & 86 & 0.19 & 100 & 0.63 \\
\hline - more than 20 times & B7_pers_sel_freq_21_99 & 0.65 & 1 & 0 & 1 & 186 & 0.71 & 86 & 0.59 & 100 & 0.09 \\
\hline
\end{tabular}




\begin{tabular}{|c|c|c|c|c|c|c|c|c|c|c|c|}
\hline \multirow[b]{2}{*}{ Variable description } & \multicolumn{5}{|c|}{ All } & \multicolumn{3}{|c|}{$\begin{array}{l}\text { Mechanical } \\
\text { Elements }\end{array}$} & \multicolumn{2}{|c|}{$\begin{array}{l}\text { Clean } \\
\text { Technology }\end{array}$} & \multirow[t]{2}{*}{$\begin{array}{c}\text { test on } \\
\text { difference }\end{array}$} \\
\hline & Variable name & mean & p50 & $\min$ & $\max$ & count & mean & $\mathrm{N}$ & mean & $\mathrm{N}$ & \\
\hline \multicolumn{12}{|c|}{ Main technology field of company (yes=1) } \\
\hline - electrical engineering & C1_comp_techarea_eleng & 0.15 & 0 & 0 & 1 & 189 & 0.13 & 85 & 0.17 & 104 & 0.41 \\
\hline$-I C T$ & C1_comp_techarea_ICT & 0.02 & 0 & 0 & 1 & 189 & 0.00 & 85 & 0.03 & 104 & 0.11 \\
\hline - semiconductors & C1_comp_techarea_semi & 0.02 & 0 & 0 & 1 & 189 & 0.00 & 85 & 0.04 & 104 & 0.07 \\
\hline - instruments & C1_comp_techarea_instr & 0.02 & 0 & 0 & 1 & 189 & 0.02 & 85 & 0.01 & 104 & 0.45 \\
\hline - chemical industry & C1_comp_techarea_chem & 0.03 & 0 & 0 & 1 & 189 & 0.01 & 85 & 0.04 & 104 & 0.26 \\
\hline - pharma, biotechnology & C1_comp_techarea_pharm & 0.01 & 0 & 0 & 1 & 189 & 0.01 & 85 & 0.00 & 104 & 0.27 \\
\hline - chemical and process engineering & C1_comp_techarea_proc & 0.02 & 0 & 0 & 1 & 189 & 0.02 & 85 & 0.02 & 104 & 0.84 \\
\hline - transportation, engines & C1_comp_techarea_trans & 0.08 & 0 & 0 & 1 & 189 & 0.11 & 85 & 0.06 & 104 & 0.22 \\
\hline - consumption & C1_comp_techarea_cons & 0.02 & 0 & 0 & 1 & 189 & 0.01 & 85 & 0.03 & 104 & 0.42 \\
\hline - mechanical engineering/machinery & C1_comp_techarea_mecheng & 0.24 & 0 & 0 & 1 & 189 & 0.36 & 85 & 0.14 & 104 & 0.00 \\
\hline - mechanical elements & C1_comp_techarea_ME & 0.05 & 0 & 0 & 1 & 189 & 0.08 & 85 & 0.02 & 104 & 0.04 \\
\hline - nanotechnology & C1_comp_techarea_NT & 0.01 & 0 & 0 & 1 & 189 & 0.00 & 85 & 0.01 & 104 & 0.36 \\
\hline - clean technology & C1_comp_techarea_CT & 0.10 & 0 & 0 & 1 & 189 & 0.01 & 85 & 0.17 & 104 & 0.00 \\
\hline - other tech. field & C1_comp_techarea_Other & 0.24 & 0 & 0 & 1 & 189 & 0.22 & 85 & 0.26 & 104 & 0.57 \\
\hline Company: Number of employees (fte) & C2_no_emp & 2317 & 300 & 2 & 100000 & 191 & 2942 & 88 & 1782 & 103 & 0.36 \\
\hline Tenure in current company (in years) & C3_tenure & 8.73 & 5 & 0 & 37 & 189 & 9.95 & 87 & 7.69 & 102 & 0.08 \\
\hline \multicolumn{12}{|c|}{ Responsibility for HR issues in company (yes $=1$ ) } \\
\hline - HR department & C4_hrm_resp_hrdep & 0.60 & 1 & 0 & 1 & 191 & 0.69 & 88 & 0.51 & 103 & 0.01 \\
\hline - One or several board members & C4_hrm_resp_board & 0.32 & 0 & 0 & 1 & 191 & 0.24 & 88 & 0.40 & 103 & 0.02 \\
\hline - Other & C4_hrm_resp_other & 0.08 & 0 & 0 & 1 & 191 & 0.07 & 88 & 0.09 & 103 & 0.62 \\
\hline \multicolumn{12}{|l|}{ Current position in company $($ yes $=1$ ) } \\
\hline - HR manager & C5_position_hrman & 0.40 & 0 & 0 & 1 & 192 & 0.50 & 88 & 0.31 & 104 & 0.01 \\
\hline - HR employee & C5_position_hremp & 0.39 & 0 & 0 & 1 & 192 & 0.35 & 88 & 0.41 & 104 & 0.39 \\
\hline - $R \& D$ manager & C5_position_rdman & 0.01 & 0 & 0 & 1 & 192 & 0.01 & 88 & 0.01 & 104 & 0.91 \\
\hline - $R \& D$ employee & C5_position_rdemp & 0.00 & 0 & 0 & 0 & 192 & 0.00 & 88 & 0.00 & 104 & . \\
\hline - Board member & C5_position_board & 0.16 & 0 & 0 & 1 & 192 & 0.11 & 88 & 0.19 & 104 & 0.13 \\
\hline - Other & C5_position_other & 0.05 & 0 & 0 & 1 & 192 & 0.02 & 88 & 0.08 & 104 & 0.09 \\
\hline
\end{tabular}




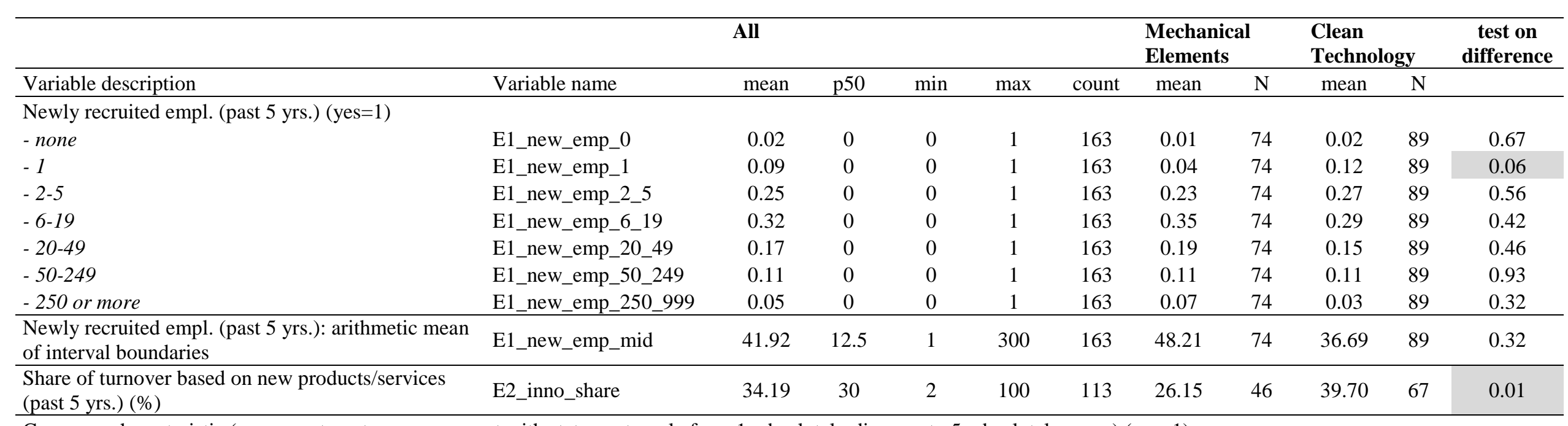

Company characteristic (agreement or strong agreement with statement, scale from $1=$ absolutely disagree to $5=$ absolutely agree) (yes $=1$ )

- economic success is based on dev. of techn.

novelties

E3_tech_agr

E3_techspec_agr

\begin{tabular}{ll}
0.75 & 1 \\
0.34 & 0 \\
0.56 & 1 \\
0.46 & 0 \\
0.62 & 1 \\
\hline
\end{tabular}

E3_pat_agr

problems to find skilled R D staff (past 2 yrs.)

- expect problems to find skilled $R \& D$ staff E3_stafffut_agr

Recruitment channel used (yes $=1$, multiple answers possible)

- print media

- online media

E4_recruit_used_print

- headhunter/consultancy companies

- career fairs

E4_recruit_used_online

E4_recruit_used_headh

E4_recruit_used_fair

E4_recruit_used_unsolic

E4_recruit_used_int

- former intern

- recommendation by $R \& D$ employees

- recommendation by other employees

E4_recruit_used_recrd

E4 recruit_used recoth

0.87

0.96

0.80

0.69

- other

E4_recruit_used_other

0.98

0.84

0.87

0.56

0

0
0
0
0
0

1
1
1
1
1

$\begin{array}{ll}165 & 0.74 \\ 164 & 0.28 \\ 165 & 0.61 \\ 164 & 0.44 \\ 165 & 0.67\end{array}$

72
72
72
72
72

0.75

$0.38 \quad 92$

$0.53 \quad 93$

0.48

0.58

93

0.81

0.17

0.28

0.67

\begin{tabular}{lllllllll}
1 & 0 & 1 & 161 & 0.96 & 70 & 0.80 & 91 & 0.00 \\
1 & 0 & 1 & 162 & 1.00 & 71 & 0.93 & 91 & 0.03 \\
1 & 0 & 1 & 161 & 0.82 & 71 & 0.78 & 90 & 0.54 \\
1 & 0 & 1 & 158 & 0.77 & 71 & 0.62 & 87 & 0.04 \\
1 & 0 & 1 & 162 & 0.99 & 71 & 0.98 & 91 & 0.71 \\
1 & 0 & 1 & 160 & 0.93 & 70 & 0.94 & 90 & 0.68 \\
1 & 0 & 1 & 162 & 0.80 & 71 & 0.87 & 91 & 0.26 \\
1 & 0 & 1 & 162 & 0.83 & 71 & 0.90 & 91 & 0.19 \\
1 & 0 & 1 & 34 & 0.50 & 14 & 0.60 & 20 & 0.56 \\
\hline
\end{tabular}




\begin{tabular}{|c|c|c|c|c|c|c|c|c|c|c|c|}
\hline \multirow[b]{2}{*}{ Variable description } & \multirow[b]{2}{*}{ Variable name } & \multicolumn{5}{|l|}{ All } & \multicolumn{2}{|c|}{$\begin{array}{l}\text { Mechanical } \\
\text { Elements }\end{array}$} & \multicolumn{2}{|c|}{$\begin{array}{l}\text { Clean } \\
\text { Technology }\end{array}$} & \multirow[t]{2}{*}{$\begin{array}{c}\text { test on } \\
\text { difference }\end{array}$} \\
\hline & & mean & p50 & $\min$ & $\max$ & count & mean & $\mathrm{N}$ & mean & $\mathrm{N}$ & \\
\hline \multicolumn{12}{|c|}{ Success of recruitment channel if used (dummy variable yes=1 if "successful" or "very successful"), scale of original variable from $1=$ not successful at all to $5=$ very successful } \\
\hline - print media & E4_recruit_print_succ & 0.19 & 0 & 0 & 1 & 140 & 0.21 & 67 & 0.18 & 73 & 0.64 \\
\hline - online media & E4_recruit_online_succ & 0.43 & 0 & 0 & 1 & 156 & 0.42 & 71 & 0.44 & 85 & 0.87 \\
\hline - headhunter/consultancy companies & E4_recruit_headh_succ & 0.37 & 0 & 0 & 1 & 128 & 0.38 & 58 & 0.36 & 70 & 0.80 \\
\hline - career fairs & E4_recruit_fair_succ & 0.25 & 0 & 0 & 1 & 109 & 0.27 & 55 & 0.22 & 54 & 0.54 \\
\hline - unsolicited application & E4_recruit_unsolic_succ & 0.30 & 0 & 0 & 1 & 159 & 0.29 & 70 & 0.30 & 89 & 0.81 \\
\hline - former intern & E4_recruit_int_succ & 0.29 & 0 & 0 & 1 & 150 & 0.26 & 65 & 0.31 & 85 & 0.55 \\
\hline - recommendation by $R \& D$ employees & E4_recruit_recrd_succ & 0.44 & 0 & 0 & 1 & 136 & 0.44 & 57 & 0.44 & 79 & 0.96 \\
\hline - recommendation by other employees & E4_recruit_recoth_succ & 0.37 & 0 & 0 & 1 & 141 & 0.36 & 59 & 0.38 & 82 & 0.79 \\
\hline $\begin{array}{l}\text { Risk taking, self-evaluation (scale } 1=\text { highly risk } \\
\text { averse to } 11=\text { highly risk seeking) }\end{array}$ & F1_risk & 6.54 & 7 & 2 & 11 & 164 & 6.38 & 72 & 6.66 & 92 & 0.28 \\
\hline \multicolumn{12}{|l|}{ Cognitive Reflection Test } \\
\hline $\begin{array}{l}\text { - Number of completed CRT questions } \\
\text { - CRT test overall score (number of correct }\end{array}$ & F2_crt_counter & 2.56 & 3 & 0 & 3 & 194 & 2.48 & 89 & 2.62 & 105 & 0.37 \\
\hline responses) & F2_crt_score & 1.89 & 2 & 0 & 3 & 150 & 1.99 & 67 & 1.81 & 83 & 0.29 \\
\hline \multicolumn{12}{|c|}{$\begin{array}{l}\text { Environmental orientation, set A (dummy variable "agree or completely agree" (yes }=1) \text {, original variable on scale from } 1=\text { completely disagree to } 5=\text { completely agree } \\
\text { - I think that environmental problems are one of the }\end{array}$} \\
\hline biggest challenges for our society. & F3_r1_agr & 0.88 & 1 & 0 & 1 & 161 & 0.83 & 72 & 0.91 & 89 & 0.14 \\
\hline $\begin{array}{l}\text { - I think that entrepreneurs and companies need to } \\
\text { take on a larger social responsibility. }\end{array}$ & F3_r2_agr & 0.78 & 1 & 0 & 1 & 161 & 0.72 & 72 & 0.82 & 89 & 0.14 \\
\hline $\begin{array}{l}\text { - Firms should take a leading role in the field of } \\
\text { environmental protection. }\end{array}$ & F3_r3_agr & 0.81 & 1 & 0 & 1 & 160 & 0.76 & 72 & 0.85 & 88 & 0.15 \\
\hline $\begin{array}{l}\text { - Firms that are environmentally oriented have } \\
\text { advantages in recruiting and retaining qualified } \\
\text { employees. }\end{array}$ & F3_r4_agr & 0.38 & 0 & 0 & 1 & 161 & 0.33 & 72 & 0.42 & 89 & 0.28 \\
\hline $\begin{array}{l}\text { - The environmental performance of a company will } \\
\text { in future be considered more and more by financial } \\
\text { institutions (e.g., for credits and ratings). }\end{array}$ & F3_r5_agr & 0.33 & 0 & 0 & 1 & 160 & 0.20 & 71 & 0.44 & 89 & 0.00 \\
\hline $\begin{array}{l}\text { - Corporate social responsibility should be part of } \\
\text { the foundations of each company. }\end{array}$ & F3_r6_agr & 0.83 & 1 & 0 & 1 & 161 & 0.83 & 72 & 0.82 & 89 & 0.83 \\
\hline
\end{tabular}




\begin{tabular}{|c|c|c|c|c|c|c|c|c|c|c|c|}
\hline \multirow[b]{2}{*}{ Variable description } & \multicolumn{5}{|c|}{ All } & \multicolumn{3}{|c|}{$\begin{array}{l}\text { Mechanical } \\
\text { Elements }\end{array}$} & \multicolumn{2}{|c|}{$\begin{array}{l}\text { Clean } \\
\text { Technology } \\
\end{array}$} & \multirow[t]{2}{*}{$\begin{array}{c}\text { test on } \\
\text { difference }\end{array}$} \\
\hline & Variable name & mean & $\mathrm{p} 50$ & $\min$ & $\max$ & count & mean & $\mathrm{N}$ & mean & $\mathrm{N}$ & \\
\hline \multicolumn{12}{|c|}{ Answering time for selected variables } \\
\hline \multicolumn{12}{|l|}{ a) Experiment on candidate choice } \\
\hline - choice task 1 & time_exp_task1 & 92.73 & 76 & 12 & 821 & 194 & 94.55 & 89 & 91.18 & 105 & 0.77 \\
\hline - choice task 2 & time_exp_task2 & 77.82 & 51 & 9 & 1151 & 188 & 90.87 & 84 & 67.28 & 104 & 0.14 \\
\hline - choice task 3 & time_exp_task3 & 69.25 & 39 & 11 & 2401 & 185 & 77.06 & 82 & 63.03 & 103 & 0.62 \\
\hline - choice task 4 & time_exp_task4 & 41.64 & 33 & 9 & 198 & 180 & 40.03 & 78 & 42.87 & 102 & 0.55 \\
\hline - choice task 5 & time_exp_task5 & 50.80 & 30 & 10 & 2417 & 179 & 40.44 & 78 & 58.80 & 101 & 0.50 \\
\hline - choice task 6 & time_exp_task6 & 33.08 & 26 & 9 & 196 & 175 & 31.82 & 77 & 34.07 & 98 & 0.58 \\
\hline - choice task 7 & time_exp_task7 & 29.39 & 25 & 6 & 215 & 170 & 28.96 & 74 & 29.72 & 96 & 0.83 \\
\hline - choice task 8 & time_exp_task8 & 34.01 & 23 & 5 & 737 & 170 & 30.97 & 74 & 36.34 & 96 & 0.57 \\
\hline - choice task 9 & time_exp_task9 & 46.79 & 23.5 & 3 & 2115 & 170 & 63.88 & 74 & 33.63 & 96 & 0.25 \\
\hline - choice task 10 & time_exp_task10 & 47.01 & 21 & 4 & 2324 & 170 & 67.53 & 74 & 31.19 & 96 & 0.22 \\
\hline average time per choice task & time_exp_av & 61.39 & 43.55 & 15.1 & 360 & 188 & 63.83 & 84 & 59.41 & 104 & 0.58 \\
\hline b) Cognitive Reflection Test & & . & . & . & . & 0 & & & & & \\
\hline - CRT task 1 & time_F2_crt1 & 113.69 & 53 & 11 & 1116 & 167 & 127.20 & 74 & 102.95 & 93 & 0.29 \\
\hline - CRT task 2 & time_F2_crt2 & 163.96 & 66.5 & 2 & 6635 & 164 & 219.15 & 73 & 119.69 & 91 & 0.24 \\
\hline - CRT task 3 & time_F2_crt3 & 97.36 & 51 & 3 & 774 & 165 & 117.24 & 74 & 81.19 & 91 & 0.08 \\
\hline Average time per CRT question & time_F2_crt_av & 124.40 & 71 & 6.3333 & 2225 & 167 & 154.21 & 74 & 100.68 & 93 & 0.09 \\
\hline
\end{tabular}


Table A.2: Descriptive indicators for technology experts.

\begin{tabular}{|c|c|c|c|c|c|c|}
\hline \multirow{2}{*}{\multicolumn{7}{|c|}{$\begin{array}{l}\text { Variable description } \\
\text { Age in } 2014 \text { (yes }=1)\end{array}$}} \\
\hline & & & & & & \\
\hline - 24 years or younger & A1_age_0024 & 0.00 & 0 & 0 & 0 & 89 \\
\hline - 25-34 years & A1_age_2534 & 0.02 & 0 & 0 & 1 & 89 \\
\hline - 35-44 years & A1_age_3444 & 0.17 & 0 & 0 & 1 & 89 \\
\hline - $45-54$ years & A1_age_4554 & 0.36 & 0 & 0 & 1 & 89 \\
\hline - $55-64$ years & A1_age_5564 & 0.30 & 0 & 0 & 1 & 89 \\
\hline - $65-74$ years & A1_age_6599 & 0.15 & 0 & 0 & 1 & 89 \\
\hline - 75 or older & A1_age_noansw & 0.00 & 0 & 0 & 0 & 89 \\
\hline $\begin{array}{l}\text { Age in 2014: arithmetic mean of interval } \\
\text { boundaries }\end{array}$ & A1_agegroupmid & 53.93 & 50 & 30 & 80 & 89 \\
\hline \multicolumn{7}{|l|}{ Gender (yes=1) } \\
\hline - male & A2_gender_male & 0.98 & 1 & 0 & 1 & 89 \\
\hline -female & A2_gender_female & 0.02 & 0 & 0 & 1 & 89 \\
\hline - no answer & A2_gender_noansw & 0.00 & 0 & 0 & 0 & 89 \\
\hline \multicolumn{7}{|l|}{ Highest education (yes $=1$ ) } \\
\hline - vocational & B1_edulev_voc & 0.13 & 0 & 0 & 1 & 89 \\
\hline - FH diploma & B1_edulev_FH & 0.34 & 0 & 0 & 1 & 89 \\
\hline - bachelor, university & B1_edulev_bach & 0.00 & 0 & 0 & 0 & 89 \\
\hline - master or diploma, university & B1_edulev_mast & 0.53 & 1 & 0 & 1 & 89 \\
\hline - other & B1_edulev_other & 0.00 & 0 & 0 & 0 & 89 \\
\hline - no answer & B1_edulev_noansw & 0.00 & 0 & 0 & 0 & 89 \\
\hline $\begin{array}{l}\text { Time elapsed since graduation in highest } \\
\text { education }\end{array}$ & B2_edu_timeel & 26.46 & 27 & 1 & 61 & 87 \\
\hline \multicolumn{7}{|c|}{ Field of education (if academic education, aggregated categories) (yes $=1$ ) } \\
\hline - engineering & B3_edu_ac_field2_eng & 0.80 & 1 & 0 & 1 & 84 \\
\hline - natural sciences (incl. med/health) & B3_edu_ac_field2_natsci & 0.18 & 0 & 0 & 1 & 84 \\
\hline - law & B3_edu_ac_field2_law & 0.00 & 0 & 0 & 0 & 84 \\
\hline - economics and business & B3_edu_ac_field2_bus & 0.01 & 0 & 0 & 1 & 84 \\
\hline - social sciences (incl. arts, languages) & B3_edu_ac_field2_soc & 0.00 & 0 & 0 & 0 & 84 \\
\hline - other & B3_edu_ac_field2_other & 0.00 & 0 & 0 & 0 & 84 \\
\hline - no answer & B3_edu_ac_field2_noansw & 0.01 & 0 & 0 & 1 & 84 \\
\hline \multicolumn{7}{|c|}{ Field of education (if vocational education, aggregated categories) (yes=1) } \\
\hline - handicraft & B3_edu_voc_field_hand & 0.20 & 0 & 0 & 1 & 5 \\
\hline - technical & B3_edu_voc_field_tech & 0.20 & 0 & 0 & 1 & 5 \\
\hline - natural sciences & B3_edu_voc_field_nat & 0.40 & 0 & 0 & 1 & 5 \\
\hline - social & B3_edu_voc_field_nat & 0.00 & 0 & 0 & 0 & 5 \\
\hline - commercial & B3_edu_voc_field_comm & 0.20 & 0 & 0 & 1 & 5 \\
\hline - other & B3_edu_voc_field_other & 0.00 & 0 & 0 & 0 & 5 \\
\hline - no answer & B3_edu_voc_field_noansw & 0.00 & 0 & 0 & 0 & 5 \\
\hline HRM specialization in education (yes $=1$ ) & B4_hrm_study & 0.00 & 0 & 0 & 0 & 89 \\
\hline \multicolumn{7}{|l|}{ Leadership/HRM experience (yes $=1$ ) } \\
\hline - none & B5_hrm_exp_none & 0.15 & 0 & 0 & 1 & 88 \\
\hline - average practical experience & B5_hrm_exp_average & 0.47 & 0 & 0 & 1 & 88 \\
\hline - expert & B5_hrm_exp_expert & 0.39 & 0 & 0 & 1 & 88 \\
\hline - professional & B5_hrm_exp_prof & 0.00 & 0 & 0 & 0 & 88 \\
\hline - no answer & B5_hrm_exp_noansw & 0.00 & 0 & 0 & 0 & 88 \\
\hline
\end{tabular}




\begin{tabular}{|c|c|c|c|c|c|c|}
\hline \multirow{2}{*}{$\begin{array}{l}\text { Variable description } \\
\text { Involvement in personnel se }\end{array}$} & Variable name & \multicolumn{2}{|c|}{ mean p50 } & $\min$ & $\max$ & count \\
\hline & 5 yrs.) (yes $=1$, multiple answer: & possible & & & & \\
\hline - none & B6_pers_sel_none & 0.25 & 0 & 0 & 1 & 88 \\
\hline - preselection by application scr & B6_pers_sel_cv & 0.36 & 0 & 0 & 1 & 88 \\
\hline - interviews, expert function & B6_pers_sel_int_exp & 0.57 & 1 & 0 & 1 & 88 \\
\hline - interviews, hr function & B6_pers_sel_int_hr & 0.02 & 0 & 0 & 1 & 88 \\
\hline - other & B6_pers_sel_oth & 0.09 & 0 & 0 & 1 & 88 \\
\hline \multicolumn{7}{|l|}{ Main technology field of company (yes=1) } \\
\hline - electrical engineering & C1_comp_techarea_eleng & 0.15 & 0 & 0 & 1 & 88 \\
\hline - ICT & C1_comp_techarea_ICT & 0.00 & 0 & 0 & 0 & 88 \\
\hline - semiconductors & C1_comp_techarea_semi & 0.01 & 0 & 0 & 1 & 88 \\
\hline - instruments & C1_comp_techarea_instr & 0.01 & 0 & 0 & 1 & 88 \\
\hline - chemical industry & C1_comp_techarea_chem & 0.05 & 0 & 0 & 1 & 88 \\
\hline - pharma, biotechnology & C1_comp_techarea_pharm & 0.00 & 0 & 0 & 0 & 88 \\
\hline - chemical and process engineering & C1_comp_techarea_proc & 0.05 & 0 & 0 & 1 & 88 \\
\hline - transportation, engines & C1_comp_techarea_trans & 0.26 & 0 & 0 & 1 & 88 \\
\hline - consumption & C1_comp_techarea_cons & 0.03 & 0 & 0 & 1 & 88 \\
\hline - mechanical engineering/machinery & C1_comp_techarea_mecheng & 0.15 & 0 & 0 & 1 & 88 \\
\hline - mechanical elements & C1_comp_techarea_ME & 0.05 & 0 & 0 & 1 & 88 \\
\hline - nanotechnology & C1_comp_techarea_NT & 0.01 & 0 & 0 & 1 & 88 \\
\hline - clean technology & C1_comp_techarea_CT & 0.05 & 0 & 0 & 1 & 88 \\
\hline - other tech. field & C1_comp_techarea_Other & 0.19 & 0 & 0 & 1 & 88 \\
\hline Company: Number of employees (fte) & C2_no_emp & 56495 & 4500 & & 500000 & 87 \\
\hline Tenure in current company (in years) & C3_tenure & 17.60 & 15 & 0 & 41 & 87 \\
\hline \multicolumn{7}{|c|}{ Responsibility for HR issues in company (yes=1) } \\
\hline - HR department & C4_hrm_resp_hrdep & 0.90 & 1 & 0 & 1 & 87 \\
\hline - One or several board members & C4_hrm_resp_board & 0.09 & 0 & 0 & 1 & 87 \\
\hline - Other & C4_hrm_resp_other & 0.01 & 0 & 0 & 1 & 87 \\
\hline \multicolumn{7}{|l|}{ Newly recruited empl. (past 5 yrs.) (yes $=1$ ) } \\
\hline - none & E1_new_emp_0 & 0.04 & 0 & 0 & 1 & 76 \\
\hline-1 & E1_new_emp_1 & 0.04 & 0 & 0 & 1 & 76 \\
\hline$-2-5$ & E1_new_emp_2_5 & 0.22 & 0 & 0 & 1 & 76 \\
\hline$-6-19$ & E1_new_emp_6_19 & 0.17 & 0 & 0 & 1 & 76 \\
\hline$-20-49$ & E1_new_emp_20_49 & 0.09 & 0 & 0 & 1 & 76 \\
\hline$-50-249$ & E1_new_emp_50_249 & 0.17 & 0 & 0 & 1 & 76 \\
\hline - 250 or more & E1_new_emp_250_999 & 0.26 & 0 & 0 & 1 & 76 \\
\hline $\begin{array}{l}\text { Newly recruited empl. (past } 5 \text { yrs.): } \\
\text { arithmetic mean of interval boundaries }\end{array}$ & E1_new_emp_mid & 110.7 & 34.5 & 1 & 300 & 76 \\
\hline $\begin{array}{l}\text { Share of turnover based on new } \\
\text { products/services (past } 5 \text { yrs.) (\%) }\end{array}$ & E2_inno_share & 36.97 & 30 & 5 & 100 & 61 \\
\hline \multicolumn{7}{|c|}{$\begin{array}{l}\text { Company characteristic (agreement with statement, scale from } 1=\text { absolutely disagree to } 5=\text { absolutely agree) } \\
\text { - economic success is based on dev. of }\end{array}$} \\
\hline $\begin{array}{l}\text { techn. novelties } \\
\text { - technology development focused on }\end{array}$ & E3_tech & 0.82 & 1 & 0 & 1 & 82 \\
\hline $\begin{array}{l}\text { CT/ME } \\
\text { - patent applications important for }\end{array}$ & E3_techspec & 0.44 & 0 & 0 & 1 & 81 \\
\hline $\begin{array}{l}\text { company success } \\
\text { - problems to find skilled } R \& D \text { staff }\end{array}$ & E3_pat & 0.70 & 1 & 0 & 1 & 81 \\
\hline (past 2 yrs.) & E3_staffnow & 0.32 & 0 & 0 & 1 & 78 \\
\hline $\begin{array}{l}\text { - expect to experience problems to find } \\
\text { skilled } R \& D \text { staff }\end{array}$ & E3_stafffut & 0.50 & 0.5 & 0 & 1 & 78 \\
\hline
\end{tabular}




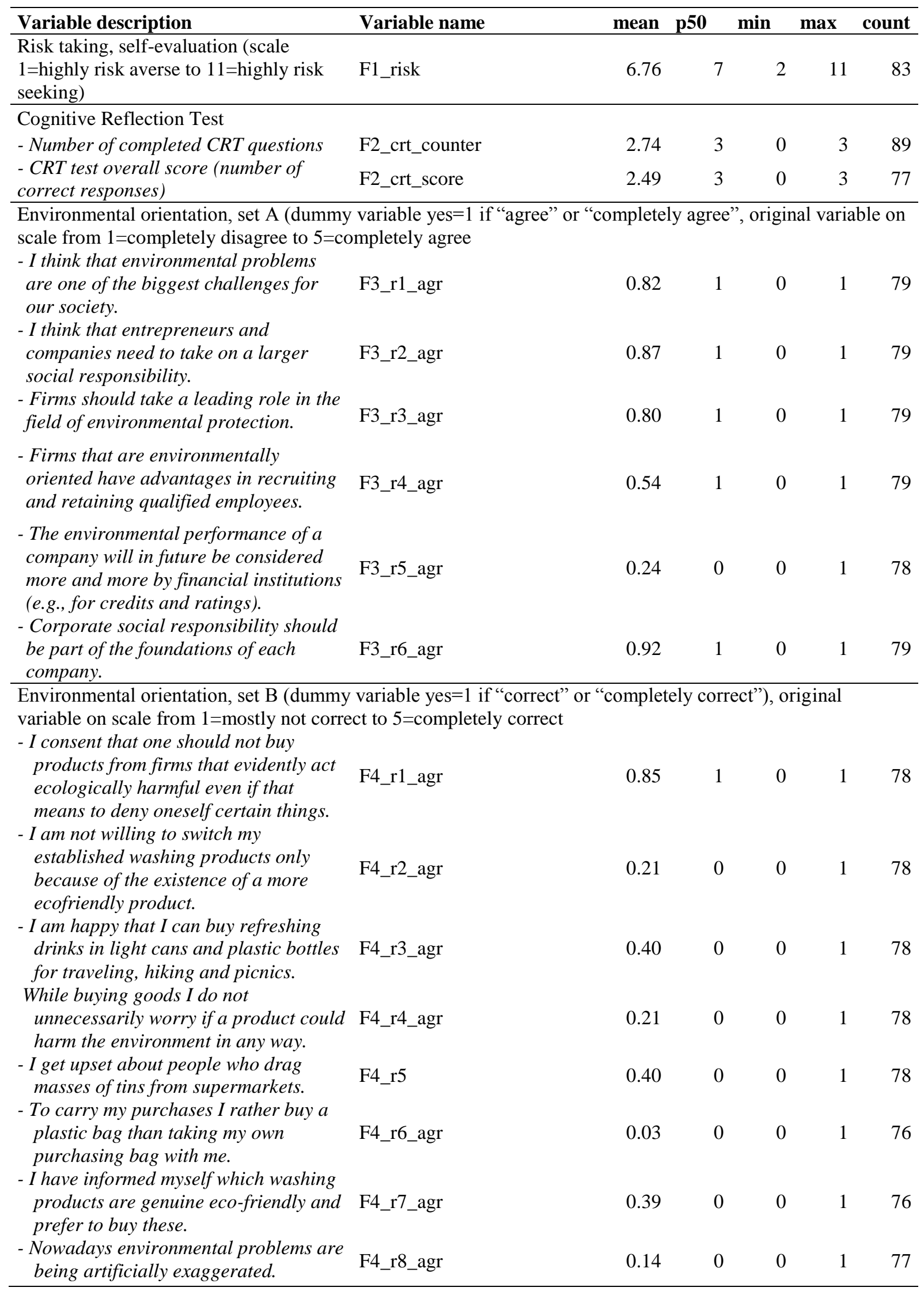




\begin{tabular}{|c|c|c|c|c|c|c|}
\hline Variable description & Variable name & mean & p50 & $\min$ & $\max$ & count \\
\hline $\begin{array}{l}\text { - I would be willing to pay a higher } \\
\text { electricity price if I knew the energy was } \\
\text { generated by alternative sources. }\end{array}$ & F4_r9_agr & 0.49 & 0 & 0 & 1 & 78 \\
\hline $\begin{array}{l}\text { - I do not even make an effort to act } \\
\text { environmentally conscious. }\end{array}$ & F4_r10_agr & 0.09 & 0 & 0 & 1 & 76 \\
\hline $\begin{array}{l}\text { - As an individual I can only do little for } \\
\text { environment protection. }\end{array}$ & F4_r11_agr & 0.14 & 0 & 0 & 1 & 79 \\
\hline $\begin{array}{l}\text { - The role of the automobile as a polluter is } \\
\text { overstated. }\end{array}$ & F4_r12_agr & 0.43 & 0 & 0 & 1 & 79 \\
\hline $\begin{array}{l}\text { - A speed limit will not help the } \\
\text { environment substantially. }\end{array}$ & F4_r13_agr & 0.29 & 0 & 0 & 1 & 79 \\
\hline $\begin{array}{l}\text { Intention to get self-employed within the } \\
\text { next } 5 \text { yrs. }\end{array}$ & F5_int_selfemp & 1.83 & 1 & 1 & 5 & 78 \\
\hline \multicolumn{7}{|l|}{ Answering time for selected variables } \\
\hline - choice task 1 & time_exp_task1 & 134.89 & 102 & 32 & 1115 & 89 \\
\hline - choice task 2 & time_exp_task2 & 94.49 & 81 & 27 & 404 & 88 \\
\hline - choice task 3 & time_exp_task3 & 75.66 & 58 & 21 & 329 & 87 \\
\hline - choice task 4 & time_exp_task4 & 60.01 & 52 & 8 & 272 & 86 \\
\hline - choice task 5 & time_exp_task5 & 50.09 & 42 & 9 & 173 & 85 \\
\hline - choice task 6 & time_exp_task6 & 81.82 & 41.5 & 9 & 2474 & 84 \\
\hline - choice task 7 & time_exp_task7 & 88.13 & 34 & 6 & 3917 & 83 \\
\hline - choice task 8 & time_exp_task8 & 46.48 & 38 & 6 & 167 & 83 \\
\hline - choice task 9 & time_exp_task 9 & 47.05 & 38 & 10 & 170 & 83 \\
\hline - choice task 10 & time_exp_task10 & 43.13 & 37 & 6 & 137 & 83 \\
\hline average time per choice task & time_exp_av & 81.22 & 59.8 & 19.8 & 452.8 & 88 \\
\hline \multicolumn{7}{|l|}{ b) Cognitive Reflection Test } \\
\hline - CRT task 1 & time_F2_crt1 & 129.34 & 88 & 26 & 981 & 82 \\
\hline - CRT task 2 & time_F2_crt2 & 138.30 & 88 & 11 & 789 & 81 \\
\hline - CRT task 3 & time_F2_crt3 & 126.80 & 44 & 8 & 1356 & 81 \\
\hline Average time per CRT question & time_F2_crt_av & 136.06 & 79.5 & 15 & 768 & 82 \\
\hline
\end{tabular}




\section{Appendix B: Conjoint experiment}

Figure B.1: Example for choice set in web-administered conjoint experiment.

D. Experiment: Fiktive Personalauswahlentscheidungen

Wen würden Sie zu einem Vorstellungsgespräch für die offene Stelle für Technologieentwicklung im Berech Clean Technology einladen? Kreuzen Sie bitte den am besten geeigneten und den am wenigsten geeigneten Kandidaten an.

\section{Auswahlset 1}

\begin{tabular}{|c|c|c|c|}
\hline & Bewerber A & Bewerber B & Bewerber C \\
\hline $\begin{array}{l}\text { Erfindertätigkeit in den } \\
\text { vergangenen } 5 \text { Jahren }\end{array}$ & $\begin{array}{l}\text { mind. eine patentierte } \\
\text { Erfindung }\end{array}$ & keine patentierte Erfindung & $\begin{array}{l}\text { mind. eine patentierte } \\
\text { Clean Technology- } \\
\text { Erfindung }\end{array}$ \\
\hline $\begin{array}{r}\text { Bisherige } \\
\text { Berufserfahrung }\end{array}$ & $\begin{array}{l}\text { eher breit gefächert } \\
\text { (Generalist) }\end{array}$ & eher spezialisiert (Experte) & $\begin{array}{l}\text { eher breit gefächert } \\
\text { (Generalist) }\end{array}$ \\
\hline Fachlicher Hintergrund & Ingenieur & Naturwissenschaftler & Ingenieur \\
\hline $\begin{array}{r}\text { Vorherrschende sonstige } \\
\text { Eigenschaft }\end{array}$ & besonders risikobereit & besonders risikobereit & besonders risikobereit \\
\hline $\begin{array}{r}\text { Vorherrschende } \\
\text { Motivation für die } \\
\text { Bewerbung }\end{array}$ & $\begin{array}{l}\text { Umweltschutz und } \\
\text { Nachhaltigkeit }\end{array}$ & $\begin{array}{l}\text { Umweltschutz und } \\
\text { Nachhaltigkeit }\end{array}$ & selbstbestimmt arbeiten \\
\hline Am besten geeignet & ( ) & 0 & 0 \\
\hline Am wenigsten geeignet & 0 & ○ & O \\
\hline
\end{tabular}

Zur Erinnerung:

Alle Bewerber haben ca. 15 Jahre Berufserfahrung und unterscheiden sich abgesehen von den in den Profilen genannten Merkmalen nicht.

(1 von 12)

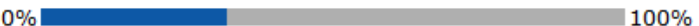

Falls Sie die Befragung zwischenzeitlich unterbrechen, können Sie sich jederzeit wieder mit Ihrem Zugangcscode einloggen und gelangen auf die letzte von Ihnen bearbeitete Fragebogenseite. Bei technischen Problemen oder sonstigen Fragen können Sie sich jederzeit an innovationsbefraqunq@uni-wuerzbura,de wenden. 
Table B.2: Attribute levels of fixed tasks.

\section{Fixed task 1}

\begin{tabular}{|c|c|c|c|c|c|c|}
\hline Fixed Choice Task experiment_Fixed1 & 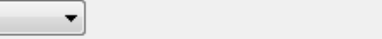 & & & & & \\
\hline Attribute & Concept \#1 & & Concept $\# 2$ & & Concept \#3 & \\
\hline 1. Fachlicher Hintergrund & 1. Ingenieur & - & 1. Ingenieur & 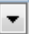 & 1. Ingenieur & $\checkmark$ \\
\hline 2. Bisherige Berufserfahrung & 1. eher spezialisiert (Experte) & - & 1. eher spezialisiert (Experte) & - & 2. eher breit gefächert (Generalist) & 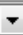 \\
\hline 3. Vorherrschende sonstige Eigenschaft & 3. besonders gut in analytischem und syst & - & 1. besonders kreativ & $\checkmark$ & 2. besonders risikobereit & - \\
\hline 4. Vorherrschende Motivation für die Bewerbung & 2. wegweisende Technologien entwickeln & - & 1. selbstbestimmt arbeiten & 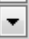 & 3. Umweltschutz und Nachhaltigke & 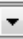 \\
\hline 5. Erfindertätigkeit in den vergangenen 5 Jahren & 3. mind. eine patentierte $[\%$ Begin Unverifie & - & 1. keine patentierte Erfindung & $\checkmark$ & 3. mind. eine patentierte $[\%$ Begin U $]$ & 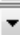 \\
\hline
\end{tabular}

\section{Fixed task 2}

\begin{tabular}{|c|c|c|c|c|c|c|}
\hline Fixed Choice Task experiment_Fixed2 & $\rightarrow$ & & & & & \\
\hline Attribute & Concept \#1 & & Concept $\# 2$ & & Concept \#3 & \\
\hline 1. Fachlicher Hintergrund & 1. Ingenieur & -1 & 1. Ingenieur & - & 1. Ingenieur & $\checkmark$ \\
\hline 2. Bisherige Berufserfahrung & 2. eher breit gefächert (Generalist) & $\rightarrow$ & 1. eher spezialisiert (Experte) & - & 1. eher spezialisiert (Experte) & 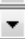 \\
\hline 3. Vorherrschende sonstige Eigenschaft & 2. besonders risikobereit & - & 1. besonders kreativ & - & 3. besonders gut in analytischem u & - \\
\hline 4. Vorherrschende Motivation für die Bewerbung & 3. Umweltschutz und Nachhaltigkeit & - & 1. selbstbestimmt arbeiten & - & 2. wegweisende Technologien enty & $\checkmark$ \\
\hline 5. Erfindertätigkeit in den vergangenen $5 \mathrm{Jahren}$ & 1. keine patentierte Erfindung & - & 1. keine patentierte Erfindung & - & 1. keine patentierte Erfindung & - \\
\hline
\end{tabular}




\section{Appendix C: Pre-test results}

Appendix C presents the results of the pre-test of the survey instrument, which was conducted with $22 \mathrm{HR}$ experts (both researchers in HRM and business practitioners with HR responsibility) and three innovation experts between December 2013 and February 2014. The median time for completing the survey was $28 \mathrm{~min}$.

After completing the survey, we asked the pre-test respondents for feedback on how well the survey worked, how realistic the fictitious candidates were, whether the candidates covered the most important candidate characteristics, to what extent the survey was relevant to the respondents' professional practice, and finally whether the number of candidate profiles to be evaluated and the overall length of the survey was reasonable and feasible.

In this context, the surveyed expert respondents rated statements on the survey on a scale from 1 (do not agree at all) to 5 (totally agree). Table C.1 summarizes the results.

The majority of the respondents evaluated the coverage of relevant topics in the overall survey and the scope and the reality of the characteristics covered by fictitious candidate profiles positive or at least fair. The reality of the fictitious profiles received the least positive evaluation, which was also mirrored in the free commentary section: Some practitioners highlighted that soft skills such as team spirit are more important than educational background and experience. We consciously left out such candidate characteristics because they mainly refer to the capacity to co-operate in larger R\&D teams, an additional dimension that we wanted to leave out of the experiment.

Furthermore, one participant criticized that in the real-life selection processes, the applicant profiles are never as homogenous as in our experiment, which is a natural consequence of standardized experiments.

As most of the applicants felt that the number of candidate profiles to be evaluated to be too large, and many also criticized the overall length of the survey, we reduced the number of choice tasks from 13 to 10 and shortened the other survey modules by about $20 \%$.

Table C.1: Expert assessment of the online survey and experiment.

\begin{tabular}{|c|c|c|c|c|c|}
\hline Inventor characteristic & $\begin{array}{l}\text { do not } \\
\text { agree at } \\
\text { all }\end{array}$ & $\begin{array}{l}\text { do not } \\
\text { agree }\end{array}$ & $\begin{array}{l}\text { partly } \\
\text { agree }\end{array}$ & agree & $\begin{array}{l}\text { totally } \\
\text { agree }\end{array}$ \\
\hline $\begin{array}{l}\text { The survey covered aspects relevant for my } \\
\text { professional practice. }\end{array}$ & 1 & 4 & 7 & 9 & 2 \\
\hline The survey was too long. & 0 & 4 & 5 & 9 & 5 \\
\hline $\begin{array}{l}\text { The profiles of the fictitious candidates were close } \\
\text { to reality. }\end{array}$ & 1 & 6 & 9 & 7 & 0 \\
\hline $\begin{array}{l}\text { The number of fictitious profiles to be evaluated } \\
\text { was too large. }\end{array}$ & 1 & 3 & 1 & 10 & 8 \\
\hline $\begin{array}{l}\text { The profiles covered the most important applicant } \\
\text { characteristics. }\end{array}$ & 1 & 3 & 6 & 11 & 2 \\
\hline
\end{tabular}

Note: $\mathrm{N}=23$ participants of the pre-test who have completed the questions about how they evaluate the online survey and the experiment. 


\section{Appendix D: Robustness checks for preference estimation}

Table D.1: Robustness check for logit models (best-choices only).

\begin{tabular}{|c|c|c|c|c|}
\hline & $\begin{array}{c}\text { HR decision } \\
\text { makers } \\
\text { (D1b) }\end{array}$ & $\begin{array}{c}\text { Technology } \\
\text { experts } \\
\text { (D2b) }\end{array}$ & $\begin{array}{c}\text { HR decision } \\
\text { makers, ME } \\
\text { (D3b) }\end{array}$ & $\begin{array}{c}\text { HR decision } \\
\text { makers, CT } \\
\text { (D4b) }\end{array}$ \\
\hline \multicolumn{5}{|c|}{ Previous patenting experience (reference: Patents in other technology field) } \\
\hline \multirow{2}{*}{ no patents } & $-0.837 * * *$ & $-0.620 * * *$ & $-0.978 * * *$ & $-0.662 * * *$ \\
\hline & $(0.0904)$ & $(0.117)$ & $(0.129)$ & $(0.0986)$ \\
\hline \multirow{2}{*}{ patents in same field } & $0.757 * * *$ & $0.374 * * *$ & $0.644 * * *$ & $0.772 * * *$ \\
\hline & $(0.0906)$ & $(0.113)$ & $(0.139)$ & $(0.115)$ \\
\hline \multicolumn{5}{|c|}{ Professional background (reference: natural sciences) } \\
\hline \multirow{2}{*}{ engineering } & $0.661 * * *$ & $0.501 * * *$ & $0.980 * * *$ & $0.421 * * *$ \\
\hline & $(0.0913)$ & $(0.122)$ & $(0.140)$ & $(0.105)$ \\
\hline \multicolumn{5}{|c|}{ Job experience (reference: specialist) } \\
\hline \multirow{2}{*}{ generalist } & -0.00174 & $0.382 * * *$ & $-0.273^{*}$ & 0.0932 \\
\hline & $(0.0999)$ & $(0.138)$ & $(0.140)$ & $(0.138)$ \\
\hline \multicolumn{5}{|c|}{ Special skill (reference: creativity) } \\
\hline \multirow{2}{*}{ pos. risk attitude } & $-0.857 * * *$ & $-1.816^{* * *}$ & $-0.978 * * *$ & $-0.801 * * *$ \\
\hline & $(0.111)$ & $(0.244)$ & $(0.166)$ & $(0.155)$ \\
\hline \multirow{2}{*}{ analyt. thinking } & $0.239 * *$ & 0.254 & $0.571 * * *$ & $0.321 * *$ \\
\hline & $(0.0996)$ & $(0.174)$ & $(0.149)$ & $(0.137)$ \\
\hline \multicolumn{5}{|c|}{ Main motivation for application (reference: independent and autonomous working) } \\
\hline \multirow{2}{*}{ technology dvlpm. } & $0.914 * * *$ & $1.045 * * *$ & $1.190 * * *$ & $1.079 * * *$ \\
\hline & $(0.103)$ & $(0.160)$ & $(0.144)$ & $(0.144)$ \\
\hline \multirow{2}{*}{ environm. + sustain. } & 0.113 & 0.128 & -0.160 & $0.367 * *$ \\
\hline & $(0.116)$ & $(0.158)$ & $(0.154)$ & $(0.162)$ \\
\hline \multirow{2}{*}{ Constant } & $-1.267 * * *$ & $-1.131 * * *$ & $-1.370 * * *$ & $-1.432 * * *$ \\
\hline & $(0.118)$ & $(0.170)$ & $(0.166)$ & $(0.162)$ \\
\hline Observations & 5343 & 3054 & 2790 & 3570 \\
\hline Pseudo R-squared & 0.124 & 0.170 & 0.192 & 0.126 \\
\hline
\end{tabular}

Notes:

Robust standard errors in parentheses, $* * * \mathrm{p}<0.01, * * \mathrm{p}<0.05, * \mathrm{p}<0.1$. 
Table D.2: Robustness check for mixed logit models (best-choices only).

\begin{tabular}{|c|c|c|c|c|}
\hline & $\begin{array}{c}\text { HR decision } \\
\text { makers } \\
\text { (D2c) } \\
\end{array}$ & $\begin{array}{c}\text { Technology } \\
\text { experts } \\
\text { (D2c) } \\
\end{array}$ & $\begin{array}{c}\text { HR decision } \\
\text { makers, ME } \\
\text { (D2c) }\end{array}$ & $\begin{array}{c}\text { HR decision } \\
\text { makers, CT } \\
\text { (D2c) }\end{array}$ \\
\hline \multicolumn{5}{|c|}{ Previous patenting experience (reference: patents in other technology field) } \\
\hline no patents & $\begin{array}{c}-1.065^{* * *} \\
(0.109)\end{array}$ & $\begin{array}{c}-0.948 * * * \\
(0.160)\end{array}$ & $\begin{array}{c}-1.378 * * * \\
(0.185)\end{array}$ & $\begin{array}{c}-0.933 * * * \\
(0.145)\end{array}$ \\
\hline patents in same field & $\begin{array}{c}0.962 * * * \\
(0.0943)\end{array}$ & $\begin{array}{c}0.651 * * * \\
(0.146)\end{array}$ & $\begin{array}{c}0.889 * * * \\
(0.159)\end{array}$ & $\begin{array}{c}1.173 * * * \\
(0.132)\end{array}$ \\
\hline \multicolumn{5}{|c|}{ Professional background (reference: natural sciences) } \\
\hline engineering & $\begin{array}{c}0.774 * * * \\
(0.108)\end{array}$ & $\begin{array}{c}0.659 * * * \\
(0.123)\end{array}$ & $\begin{array}{c}1.245^{* * *} * \\
(0.180)\end{array}$ & $\begin{array}{c}0.586^{* * * *} \\
(0.143)\end{array}$ \\
\hline \multicolumn{5}{|c|}{ Job experience (reference: specialist) } \\
\hline generalist & $\begin{array}{r}-0.0297 \\
(0.112)\end{array}$ & $\begin{array}{c}0.571 * * * \\
(0.164)\end{array}$ & $\begin{array}{c}-0.337 * \\
(0.191)\end{array}$ & $\begin{array}{c}0.00944 \\
(0.149)\end{array}$ \\
\hline \multicolumn{5}{|c|}{ Special skill (reference: creativity) } \\
\hline pos. risk attitude & $\begin{array}{c}-1.166 * * * \\
(0.131)\end{array}$ & $\begin{array}{c}-3.139 * * * \\
(0.431)\end{array}$ & $\begin{array}{c}-1.442 * * * \\
(0.241)\end{array}$ & $\begin{array}{c}-1.258 * * * \\
(0.195)\end{array}$ \\
\hline analyt. thinking & $\begin{array}{c}0.236 * * \\
(0.111)\end{array}$ & $\begin{array}{l}-0.0811 \\
(0.192)\end{array}$ & $\begin{array}{c}0.574 * * * \\
(0.184)\end{array}$ & $\begin{array}{l}0.266^{*} \\
(0.160)\end{array}$ \\
\hline \multicolumn{5}{|c|}{ Main motivation for application (reference: independent and autonomous working) } \\
\hline technology dvlpm. & $\begin{array}{c}1.187 * * * \\
(0.125)\end{array}$ & $\begin{array}{c}1.213 * * * \\
(0.200)\end{array}$ & $\begin{array}{c}1.282 * * * \\
(0.228)\end{array}$ & $\begin{array}{l}1.310 * * * \\
(0.185)\end{array}$ \\
\hline environm. + sustain. & $\begin{array}{c}0.174 \\
(0.132)\end{array}$ & $\begin{array}{c}0.293 \\
(0.198)\end{array}$ & $\begin{array}{c}-0.308 \\
(0.228)\end{array}$ & $\begin{array}{c}0.530 * * * \\
(0.194)\end{array}$ \\
\hline Observations & 5343 & 2553 & 2349 & 2994 \\
\hline
\end{tabular}

Notes:

Standard errors in parentheses, $* * * \mathrm{p}<0.01$, ** $\mathrm{p}<0.05, * \mathrm{p}<0.1$. 
Table D.3: Robustness check for mixed logit models (second-best choices only).

\begin{tabular}{|c|c|c|c|c|}
\hline & $\begin{array}{c}\text { HR decision } \\
\text { makers } \\
(\text { D3d }) \\
\end{array}$ & $\begin{array}{c}\text { Technology } \\
\text { experts } \\
\text { (D3d) } \\
\end{array}$ & $\begin{array}{c}\text { HR decision } \\
\text { makers, ME } \\
\text { (D3d) }\end{array}$ & $\begin{array}{c}\text { HR decision } \\
\text { makers, CT } \\
\text { (D3d) }\end{array}$ \\
\hline \multicolumn{5}{|c|}{ Previous patenting experience (reference: patents in other technology field) } \\
\hline no patents & $\begin{array}{c}-0.873 * * * \\
(0.101)\end{array}$ & $\begin{array}{c}-0.827 * * * \\
(0.167)\end{array}$ & $\begin{array}{c}-1.242 * * * \\
(0.215)\end{array}$ & $\begin{array}{c}-0.807 * * * \\
(0.127)\end{array}$ \\
\hline patents in same field & $\begin{array}{l}0.469 * * * \\
(0.117)\end{array}$ & $\begin{array}{c}0.411 * * \\
(0.174)\end{array}$ & $\begin{array}{l}0.386^{*} \\
(0.199)\end{array}$ & $\begin{array}{l}0.595 * * * \\
(0.152)\end{array}$ \\
\hline \multicolumn{5}{|c|}{ Professional background (reference: natural sciences) } \\
\hline engineering & $\begin{array}{r}0.357 * * * \\
(0.0979)\end{array}$ & $\begin{array}{l}0.499 * * * \\
(0.134)\end{array}$ & $\begin{array}{l}0.921 * * * \\
(0.245)\end{array}$ & $\begin{array}{c}0.153 \\
(0.110)\end{array}$ \\
\hline \multicolumn{5}{|c|}{ Job experience (reference: specialist) } \\
\hline generalist & $\begin{array}{l}-0.107 \\
(0.102)\end{array}$ & $\begin{array}{c}0.209 \\
(0.195)\end{array}$ & $\begin{array}{l}-0.288 \\
(0.194)\end{array}$ & $\begin{array}{c}-0.0894 \\
(0.131)\end{array}$ \\
\hline \multicolumn{5}{|c|}{ Special skill (reference: creativity) } \\
\hline pos. risk attitude & $\begin{array}{c}-0.747 * * * \\
(0.120)\end{array}$ & $\begin{array}{l}-2.112 * * * \\
(0.309)\end{array}$ & $\begin{array}{c}-1.009 * * * \\
(0.222)\end{array}$ & $\begin{array}{c}-0.760 * * * \\
(0.171)\end{array}$ \\
\hline analyt. thinking & $\begin{array}{c}0.296 * * \\
(0.129)\end{array}$ & $\begin{array}{l}-0.222 \\
(0.219)\end{array}$ & $\begin{array}{c}0.809 * * * \\
(0.284)\end{array}$ & $\begin{array}{l}0.0893 \\
(0.167)\end{array}$ \\
\hline \multicolumn{5}{|c|}{ Main motivation for application (reference: independent and autonomous working) } \\
\hline technology dvlpm. & $\begin{array}{c}0.542 * * * \\
(0.130)\end{array}$ & $\begin{array}{l}0.721 * * * \\
(0.224)\end{array}$ & $\begin{array}{l}0.805 * * * \\
(0.248)\end{array}$ & $\begin{array}{c}0.474 * * * \\
(0.164)\end{array}$ \\
\hline environm. + sustain. & $\begin{array}{c}0.00986 \\
(0.122)\end{array}$ & $\begin{array}{r}-0.0727 \\
(0.206)\end{array}$ & $\begin{array}{l}-0.429 * \\
(0.245)\end{array}$ & $\begin{array}{l}0.297 * * \\
(0.142)\end{array}$ \\
\hline Observations & 3562 & 1702 & 1566 & 1996 \\
\hline
\end{tabular}

Notes:

Standard errors in parentheses, $* * * \mathrm{p}<0.01, * * \mathrm{p}<0.05, * \mathrm{p}<0.1$. 
Table D.4: Robustness check for HR decision makers in CT companies with and without EPOpatents.

\begin{tabular}{lcc}
\hline & $\begin{array}{c}\text { with EPO } \\
\text { patents } \\
\text { (D4a) }\end{array}$ & $\begin{array}{c}\text { without EPO } \\
\text { patents } \\
\text { (D4b) }\end{array}$ \\
\hline Previous patenting experience (reference: patents in other technology field) \\
no patents & $-1.034^{* * *}$ & $-0.758^{* * *}$ \\
& $(0.149)$ & $(0.120)$ \\
patents in same field & $1.004^{* * *}$ & $0.820^{* * *}$ \\
& $(0.147)$ & $(0.117)$ \\
Professional background (reference: natural sciences) & & \\
engineering & $0.406 * *$ & $0.400^{* * *}$ \\
Job experience (reference: specialist) & $(0.165)$ & $(0.127)$ \\
generalist & & \\
Special skill (reference: creativity) & -0.0909 & 0.0295 \\
pos. risk attitude & $(0.212)$ & $(0.129)$ \\
& & \\
analyt. thinking & $-1.034^{* * *}$ & $-0.895^{* * *}$ \\
Main motivation for application (reference: independent and autonomous working) & $(0.188)$ & $(0.201)$ \\
technology dvlpm. & $1.244^{* * *}$ & $0.638^{* * *}$ \\
environm. + sustain. & $(0.167)$ & $(0.138)$ \\
\hline Observations & $0.795^{* * *}$ & 0.0572 \\
\hline
\end{tabular}

Notes:

Standard errors in parentheses, $* * * \mathrm{p}<0.01$, ** $\mathrm{p}<0.05, * \mathrm{p}<0.1$. 